\title{
Sınıf Öğretmenlerinin İş Yükü Algısı ile Mesleki Tükenmişlik Düzeyleri Arasındaki İlişki*
}

\section{Mehmet Ali ÖZTÜRK ${ }^{* *}$ ve Mustafa ERDEM ${ }^{* * *}$}

Öz: $\mathrm{Bu}$ araştırmanın genel amacı, Türkiye'de Millî Eğitim Bakanlığına bağlı resmi ilkokullarda görev yapan sınıf öğretmenlerinin iş yükü algısı ile mesleki tükenmişlikleri arasındaki ilişki düzeyini belirlemektir. Araştırma ilişkisel tarama modelindedir. Araştırmanın hedef evrenini Samsun il merkezinde yer alan Atakum, Canik ve İlkadım ilçelerinde 2017-2018 eğitim öğretim yılında görev yapan 1475 sinıf öğretmeni oluşturmaktadır. Araştırmanın örneklemini bu ilçelerdeki 329 öğretmen oluşturmaktadır. Araştırma verilerinin toplanmasında Kişisel Bilgi Formu, Öğretmenlerde İş Yükü Algısı Ölçeği ve Öğretmen Mesleki Tükenmişlik Ölçeği kullanılmıştır. Araştırma sonucunda öğretmenlerin iş yüklerinin ağır olmadığı ve mesleki tükenmişliklerinin düşük düzeyde olduğu ortaya çıkmıştır. Cinsiyet, medeni durum ve mesleki kıdem değişkenine göre öğretmenlerin hem iş yükü algıları hem de mesleki tükenmişlikleri anlamlı farklılık göstermemektedir. Yaş değişkenine göre öğretmenlerin iş yükü algıları farklılaşmamakta ancak mesleki tükenmişlikleri anlamlı bir farklılık göstermektedir. 41-50 yaş grubundaki öğretmenler diğer yaş gruplarındaki öğretmenlere göre daha fazla mesleki tükenmişlik göstermektedir. Hem toplamda hem de alt boyutlarda iş yükü algısı ile mesleki tükenmişlik arasında anlamlı, pozitif ve orta düzeyde bir ilişki olduğu görülmektedir. İş yükü algısıyla en yüksek ilişki "fiziksel ve duygusal tükenmişlik" alt boyutunda görülürken en düşük ilişki “mesleğe ilişkin duygusal tükenmişlik ve başarısızlık” alt boyutunda görülmektedir.

Anahtar Kelimeler: İş yükü, tükenmişlik, sınıf öğretmenleri.

\footnotetext{
*Yüksek lisans tez çalışmasından üretilmiştir.

**Bilim Uzmanı, Çarşamba Cemil Meriç İlkokulu, Samsun, maliozturk0055@gmail.com, ORCID: 0000-0002-9751-9882

***Doç. Dr., Kırşehir Ahi Evran Üniversitesi Eğitim Fak., Kırşehir, merdem50@gmail.com, ORCID: 0000-0001-8595-0504
} 


\section{The Relationship Between the Perception of Workload and the Occupational Burnout Levels of Classroom Teachers}

Abstract: The general purpose of the research is to determine the relationship between workload perception and occupational burnout of the classroom teachers working at the primary schools under supervision Ministry of Education in Turkey. The relational screening model was used in the research. The target universe of the research is composed of 1475 classroom teachers working in Atakum, Canik and İlkadım districts at the province center of Samsun in the 2017-2018 academic year. The sample of the research consists of 329 teachers in these districts. Personel Information Form, Workload Perception Scale for Teachers and Teachers Occupational Burnout Scale were used for the collection of research data. As a result of the research it has been found that the workload of the teachers is not anerous and their occupational burnout is low level. According to the variables of gender, marital status and occupational seniority, both of the workload perceptions and the occupational burnout of the teachers do not show a significant difference. The teachers' workload perceptions do not vary according to age, but the occupational burnout of the teachers shows a significant difference. Between the 41-50 years old teachers show the occupational burnout more than the teachers at the other age groups. The relationship between the workload perception and the occupational burnout in both total and sub-dimensions is significant, positive and moderate. The lowest relationship was found between "occupational emotional burnout and failure” sub-dimension while the highest relationship between workload perception and "physical and emotional burnout” sub-dimension was observed.

Keywords: Workload, burnout, classrom teachers.

\section{Giriş}

Dünyadaki değişim rüzgârından birçok alan etkilendiği gibi Türk eğitim sistemi de etkilenmektedir. Gelişen teknoloji, değişen ihtiyaçlar ve artan beklentilerle birlikte Türk eğitim sistemi kendini sürekli güncel tutmak için teknolojik, fiziksel, donanımsal ve müfredat gibi alanlarda her geçen yıl çeşitli atılımlar göstermektedir. Eğitim sisteminin önemli yap1 taşlarından olan öğretmenlere getirilen yenilikler, onların görev, sorumluluk ve iş yüklerini farklılaştırmaktadır. Buna bağlı olarak eğitim kalitesinden ödün vermek istemeyen öğretmenlerin mesleki tükenmişlik düzeyleri de yenilikler karşısında etkilenebilmektedir.

Öğretmenlere gereğinden fazla iş yükü verilerek tükenmişlik hâli doğurmak öğretmenlerin mesleklerini gerektiği gibi icra etmesinin önüne geçebilir. Altından 
kalkamayacağı görevler verildiğinde öğretmenler fazla iş yükü altında ezilebilir, kendilerini yorgun ve bitkin hissedebilirler. $\mathrm{Bu}$ durum öğretmenlerin meslek hayatını etkileyerek tükenmişliklerinin artmasına ve verimliliklerinin düşmesine sebep olabilir.

Öğretmenler farklı okul türlerinde çalışmalarına bağlı olarak farklı iş yüküne ve tükenmişlik düzeyine sahip olabilir. İlkokul öğretmenlerinin sahip oldukları iş yükü ile ortaokul öğretmenlerinin iş yükü farklı olabilir. Aynı zamanda ortaokul öğretmenlerinin iş yükü ile lise öğretmenlerinin iş yükü de farklı olabilir. Bu durum okul türlerinin farklı ihtiyaç ve hedeflere sahip olmalarından kaynaklanabilir. Bir ilkokulun hedefi öğrencilerini temel düzeyde donanımlı hâle getirerek ortaokula hazırlamak, ortaokulun hedefi öğrencileri yeterli bilgi ve beceri sahibi yaparak ihtiyaçları, ilgileri ve başarı seviyesi doğrultusunda doğru liseye yönlendirmek, lisenin hedefi ise öğrencileri en iyi şekilde yetiştirerek ilgileri ve hayattan beklentileri doğrultusunda üniversitelerin çeşitli bölümlerine yerleştirmektir. Bu bağlamda öğretmenlerin iş yükü algısı ve mesleki tükenmişlik düzeylerinin belli bir okul türüne göre incelenmesinin uygun olacağı düşünülmektedir.

\section{İș Yükü}

İş yükü kavramının alanyazındaki en eski tanımlardan biri Johannsen (1979) tarafından yapılmıştır. Johannsen iş yükü kavramını talimatlar ve görev süresi gibi çevresel faktörlerle birlikte motivasyon, beceri ve deneyim gibi çalışanın çabasını da kapsayan bir şemsiye olarak tanımlamıştır (akt. Xhako, 2017).

Bir başka tanımda ise iş yükü, belirli bir zamanda belirli kalitede yapılması gereken iş miktarı olarak ifade edilmektedir. İş yükü örgüt açısından ele alındığında verimliliğii, bireysel açıdan ele alındığında ise işi yapmak için harcanan zaman ve enerjiyi ifade etmektedir. Gereğinden fazla iş yükü birey üzerinde stres oluşturduğu gibi gereğinden az iş yükü de birey üzerinde stres meydana getirmektedir (Maslach ve Leiter, 1997).

İş yüküyle ilgili tanımlara bakıldığında görev isteği, performans, çaba ve algılamalar üzerinde yoğunlaşıldığı görülmektedir. Bu durum çalışana yüklenen görev arttıkça iş yükünün artabileceğine, çalışanın performansının iş yüküyle ilişkili olduğuna işaret etmektedir. İş yükünde zihinsel ve fiziksel çabanın yanı sıra duygusal çabanın da yeri olduğu, ayrıca duygusal çaba algısının iş yükü ölçümünde önemli olduğu görülmektedir (Atik, 2015).

Kurum ikliminin ve işgörenlerin çalıştıkları kuruma karşı hissettikleri aidiyet duygusunun önem kazandığı günümüz çalışma hayatında, iş yükü kritik bir role sahiptir. 
Nitekim ağır iş yükünün örgütsel bağlılı̆̆ anlamlı derecede etkilediği ve iş yükünün artması sonucunda bireyin işinden ayrılma niyetinin de artış gösterdiği görülmektedir (Jones, Chonko, Rangarajan ve Roberts, 2007).

Çalışan başına düşen iş hacmi olarak da ifade edilen iş yükünün birçok bileşeni vardır. Bu bağlamda çalışma süreleri, üretim miktarı, icra edilen faaliyetlere ilişkin duygusal talepler bile iş yükünün algılanmasına sebep olabilmektedir (Spector ve Jex, 1998). Nitekim işveren tarafından basit gibi görünen ilave görev, talep ve beklentiler, çalışanların omuzlarına binmekte ve çalışanlarda fazladan bir iş yüküne dönüşmektedir.

İş yükü konusu insan kaynakları yönetiminde ve ergonomi biliminde farklı şekillerde ele alınmaktadır. İnsan kaynakları yönetimi açısından iş yükü konusu niteliksel ve niceliksel olmak üzere iki kavram üzerinden açıklanmaktadır (Tortop, Aykaç, Yayman ve Özer, 2007). Alanyazında iş yükü ile ilgili başka bir ayrım ise fiziksel ve zihinsel iş yüküdür. Bunların yanında iş yüküne bağlı farklı alt kavramlara da rastlamak mümkündür. Bu çalışmada iş yükü niteliksel, niceliksel, fiziksel ve zihinsel olarak sınıflandırılmıştır.

Niteliksel iş yükü, çalışanların işlerini yapmaları için gerekli olan temel bilgi ve yeteneklere sahip olmadıklarını hissettiklerinde ya da o iş için gerekli olan performans düzeyinin çok yüksek olduğu durumlarda ortaya çıkmaktadır (Solmuş, 2004). Alanyazında yer alan bir tanıma göre niteliksel iş yükü, işi yapacak kişi ile işin nitelikleri arasında oluşan ve işgörenin aleyhine olan bir uyumsuzluktur (Cam, 2004).

Niteliksel iş yükü, yapılacak işin zor olduğu durumlarda çalışanların bilgi ve becerisi belirlenen işi yapmak için yeterli olmadığı durumlarda ortaya çıkmaktadır. Bu durum çalışanları olumsuz etkileyecek, basit ve kolay işlerde dahi daha düşük performans göstermelerine sebep olacaktır. Bunların yanı sıra belirgin olmayan görevlerin verilmesi, düşük düzeyde sosyal destek, bilgi fazlalığı, uyumsuz ve uygunsuz eğitim, akşam veya hafta sonu çalışılmasını gerektiren görevler ve muhatap olunan insan sayısının fazlalığı niteliksel iş yükünü ortaya çıkaran faktörlerdendir (Turgut, 2011).

Bu bağlamda çalışanların iş yükü, ideal ölçülerin üzerinde veya altında ise niteliksel iş yükünden kaynaklanan bir sorundan bahsedilebilir. Aşırı veya az iş yükü ya da kısaca iş yükü uyumsuzluğu bireyleri tükenmişliğe itebilmektedir. Birey üzerinde olumsuzluk yaratan koşulların gözden geçirilerek iyileştirilmesi ise bireyin tükenmişlik yaşama ihtimalini düşürebilir (Özkalp ve Kırel, 2018). 
Niceliksel iş yükü, bireyin yapacağı belirli bir iş için zamanın yetersiz olması ya da belirli bir zamanda yapılacak çok farklı işlerin olması şeklinde ifade edilmektedir. Bu tanıma göre işlerin önceden belirlenen sürede bitirilmiş olmasını gerektiren bir çalışma düzeni, işgörende gerilim yaratan aşırı yüklenme türüdür (Cam, 2004; Eroğlu, 1998).

Niceliksel iş yükünü artıran etmenler arasında yapılan işin sürekli dikkat istemesi ve karmaşık bilgiler içermesi sayılabilir. Ayrıca işin tamamlanması için belirli bir çalışma düzenine ihtiyaç olması, üst düzeyde kararlar almayı gerektirmesi ve fazlaca teknik bilgiler içermesi de niceliksel iş yükünü artırabilir (Atik, 2015).

$\mathrm{Bu}$ bağlamda bireyin yapacağ 1 iş için verilen süre, o işin gerektirdiği ideal sürenin altında veya üzerinde ise niceliksel iş yükünden kaynaklanan bir sorundan bahsedilebilir. İşin tamamlanması için çalışana verilen süre yetersiz ise niceliksel iş yükü ağır, verilen sürenin işin gerektirdiği ideal süreden fazla olması durumunda ise niceliksel iş yükü hafif olacaktır. Sonuçta iş yükünün gerekenden fazla ya da az olması çalışanlarda stres, fiziksel ve ruhsal yorgunluk, tükenmişlik, iş tatmininde azalma, depresyon gibi pek çok değişkenin de öncülü olarak kabul edilmektedir (Çelik, 2016; Samancı ve Basım, 2018).

Fiziksel iş yükü, işgörenin bir işi yaparken harcadığı fiziksel kaynakların ölçülebilir ifadesidir. Fiziksel iş yükü genellikle harcanan enerjinin miktarıyla ölçülmektedir. Bu durum çalışanın işi yaparken oturuyor veya yürüyor olması, fiziksel duruşu, işin sıklığı veya monotonluğu gibi etmenleri göz önünde bulundurmayı gerektirmektedir (Ordukaya, 2011).

Fiziksel iş yükü, çalışan tarafından yapılan işin miktarı ile fizyolojik olaylar arasındaki ilişkidir (Şimşek, 1994). Çalışanların yapacakları işe yönelik enerjilerinin yetmediği bir durumda iş yükü artabilmektedir. Ancak fiziksel iş yükü sadece çalışanların kapasiteleri ile ilgili değildir. Yapılacak işin niteliği de fiziksel iş yükünü etkileyen etmenlerden sayılabilmektedir. Çalışanın işi yapabilmesi için gereken duruş şekli ve ayakta kalma miktarı da fiziksel iş yükünü artıran faktörler arasında gösterilebilir (Atik, 2015).

Zihinsel iş yükü, işgörenlerin iş yapmaları esnasında katlandıkları zihinsel faaliyetlerin toplamıdır (Kramer, 1990). Diğer bir tanımda hesaplama, karar verme, iletişim kurma, hatırlama ve araştırma gibi zihinsel ve algısal faaliyetlerin meydana getirdiği iş yükü olarak da ifade edilmektedir (Dağdeviren, Eraslan ve Kurt, 2005).

Zihinsel iş yükü, işgörenlerin bilgiyi işleme kapasitelerinin yetersizliği ya da işverenin taleplerini karşılamak için kullandıkları zihinsel aktivitelerin yetersizliği durumunda ortaya 
çıkmaktadır (Eggemeier, Wilson, Kramer ve Damos, 1991). Zihinsel iş yükü arttıkça çalışanlarda performans düşmekte, görevi yerine getirme süresi artmakta, hatalar çoğalmakta, birim zamanda yapılan iş miktarı azalmakta ve diğer konularla ilgilenmek için daha az kapasite kalmaktadır (Huey ve Wickens, 1993).

\section{Tükenmişlik}

Tükenmişlik ilk kez Freudenberger (1977) tarafından başarısızlık, yıpranma, güç ve enerji kaybı ya da insanın iç kaynaklarında karşılanamayan istekler sonucu ortaya çıkan tükenme durumu olarak tanımlanmıştır (akt. Bolat, 2011). Farklı bir tanımda tükenmişlik, başkalarına yardım sağlayan meslek gruplarında çalışan bireylerde çalışma ortamının ve gerekliliklerinin bir sonucu olarak görülen, idealizm, amaç ve enerjide sürekli olarak artan bir kayıp şeklinde ifade edilmiştir (Edelwich ve Brodsky, 1980).

Maslach ve Jackson (1981) tarafından tükenmişlik, insanda ortaya çıkan fiziksel bitkinlik, uzun süren yorgunluk, çaresizlik ve umutsuzluk duyguları ile birlikte bireyin işine, hayata ve insanlara karşı gösterdiği olumsuz tutumları kapsayan fiziksel ve zihinsel boyutlu bir sendrom olarak tanımlanmıştır. Daha yalın bir ifadeyle tükenmişlik, işi gereği insanlarla yoğun bir ilişki içerisinde olan bireylerde görülen duygusal tükenme, duyarsızlaşma ve düşük kişisel başarı hissi olarak ifade edilmektedir (Maslach, 1982; Maslach, Schaufeli ve Leiter, 2001). Maslach ve arkadaşlarının yaptığı bu tanım, tükenmişlik kavramı için en çok kullanılan ve kabul gören tanımdır.

Tükenmişlik kavramı, yukarıdaki tanımlardan da anlaşılacağı üzere çalışma hayatı sağlığıyla ilişkilidir. Çünkü bireydeki yüksek tükenmişlik, çalışma hayatının kalitesini düşürecek ve iş sağlığını olumsuz etkileyecektir. Bunun yanı sıra tükenmişlik kavramı, uzun süreli devam eden kronikleşmiş stres durumunu ifade etmek için kullanıldığ gibi çalışma hayatında iş doyumsuzluğu kavramına denk olarak da kullanılmıştır (Sürgevil, 2006).

Öğretmenler için tükenmişlik 4 alt boyutta ele alınmaktadır. Mesleğe ilişkin duygusal tükenmişlik ve başarısızlık alt boyutu bireyin mesleğiyle bağlantılı olarak kendini nasıl değerlendirdiğiyle ve öğretmenlik mesleğinin beklentilerini karşılayıp karşılamadığıyla ilgilidir. Öğrencilere duyarsızlaşma alt boyutu öğretmenin öğrencilere yönelik duyarsızlığını, bıkkınlığını, mesafeli duruşunu ve olumsuz tutumlarını ifade etmektedir. Fiziksel ve duygusal tükenmişlik alt boyutu öğretmenlerin kendilerini stresli, öfkeli, yorgun, fiziksel ve duygusal enerjilerinin tükenmiş olduğunu hissetmeleriyle ilgilidir. Meslektaşlara ve yöneticilere 
duyarsızlaşma alt boyutu ise öğretmenlerin meslektaşlarıyla ilişki kurmak istememesi ve yöneticiler tarafından desteklenmemesini ifade etmektedir (Yellice Yüksel, Kaner ve Şekercioğlu, 2008).

Tükenmişlikle ilgili araştırmalara bakıldığında cinsiyet, yaş, eğitim düzeyi, medeni durum, çocuk sahibi olma veya çocuk sayısı, güdülenme, işkoliklik, bireysel beklentiler, stres ve mesleki doyum gibi değişkenler tükenmişliğin kişisel sebepleri olarak sıkça görülebilmektedir (Akten, 2007). Araştırmalarda evlilere göre bekârlarda daha yüksek tükenmişlik yaşandığı sıkça görülebilmektedir. Yaş değişkenine bakıldığında ise yaşlılara oranla gençlerde daha yüksek tükenmişlik görüldüğü sıkça saptanabilmektedir (Izgar, 2000).

Tükenmişliğin çevresel (örgütsel) sebepleri olarak örgütün yapısı, yapılan işin niteliği, çalışma saatleri, nöbet, fazla mesai, iş yerinin fiziksel yeterlilikleri, iş yerinde uygulanan kurallar, iş yükünün fazlalığı, alınan kararlarda söz sahibi olma düzeyi, ücret miktarı, rol belirsizliği, geri bildirim eksikliği ve örgüt içi ilişkiler sayılabilir (Bakan ve Tombak, 2014). Araştırmalara bakıldığında tükenmişliğin örgütsel sebeplerinden biri olarak, örgütlerde çalışanlar arası ilişkilerin sıklığı ve yoğunluğu arttıkça duygusal yönden tükenme artmaktadır. Diğer taraftan örgütlerde insan ilişkilerinin yoğunluğu azaldıkça insan ilişskilerinde gerilim ve çatışma azalmakta, buna bağlı olarak da tükenmişliğin daha az yaşandığı gözlenebilmektedir (Izgar, 2000).

Düşük performans gösterme, verimde azalma, hizmetin niteliğinde bozulma, örgütsel bağlılıkta azalma, ani öfkelenme, cilt hastalıkları, psikolojik sorunlar, başka iş alanlarına transfer olma isteği, uykusuzluk, aile hayatında huzursuzluk, öz saygıda azalma ve hizmet verilen kişilere hatalı uygulamalar gibi olumsuzluklar da tükenmişliğin sonuçları arasında gösterilebilir (Sürgevil, 2006). Tükenmişlik sendromu yaşayan bireyler sıkıntılarını azaltabileceğine inanarak sigara, içki, uyuşturucu gibi maddeleri tüketebilmekte ve zamanla bu maddelere bağımlı hale gelebilmektedir (Izgar, 2000). Bunlar, tükenmişliğin ciddi ve geri dönülemez sonuçlar doğurduğunu göstermektedir.

Yüksek düzeydeki tükenmişlik kişinin amaçlarına ulaşmasını engellemektedir. Hedeflenen amaçlara ulaşılamaması sonucu ortaya çıkan ruhsal ve psikolojik durumlar kişiler arasında anlaşmazlıklara sebep olur. Böylece iş yerinde çalışma ahengi ve huzuru bozulur, çatışmalar baş gösterir. Kişi böylece psikolojik tatminsizliğe uğrayabilir. Hangi nedene bağlı olursa olsun tatminsizliğe uğrayan kişi, çeşitli davranış bozuklukları içine girer (Yılmaz Toplu, 2012). 
Tükenmiş çalışanların çok sayıda olduğu bir örgüt çevredeki değişimlere uyum sağlamak için kendi yapı ve süreçlerindeki değişiklikleri kolaylıkla gerçekleştiremez. Tükenmişlik örgütün kendini yenilemesini ve üretkenliğini engeller. Aynı zamanda bireyin iş arkadaşlarıyla ve örgütten hizmet alan insanlarla verimli bir şekilde çalışma kapasitesini düşürür, hatta bireyi örgütten kopma noktasına getirebilir (Maslach ve Leiter, 1997).

Tükenmişliği önlemek için atılması gereken ilk adım ortada bir sorun olduğunu ya da mevcut şartlar altında sorun oluşabileceğini kabul etmektir. Bunu sağladıktan sonra hem bireyler hem de örgütler için çözüm daha kolay olacaktır. Öyle ise tükenmişliği önlemek için hem bireylerin hem de örgütlerin dikkat etmesi gereken bazı hususlar vardır.

Bireyler tükenmişliği önlemek için çalışma hayatında gerçekçi hedeflere yönelmelidir. Bireyin hedef belirlemesinde ona danışmanlık yapılması ve hedeflerini kendisinin belirlemesine olanak sağlanması işgörenlerin dayanıklılık düzeyini artırmaktadır. Gerçekçi, özgün ve ulaşılabilir hedefler konulması işi başarma duygusunu geliştirmekte ve tükenmişliği önlemektedir. Ayrıca düzenli beslenme, dinlenme, çeşitli egzersizlerle gevşeme ve işe bir süre ara verme de tükenmişliği önlemede bireysel yöntemler arasındadır (Türkmen, 2010).

Tükenmişliği önlemek için bireylerin uygulayacakları yöntemler yetersiz kalabilir. Bu durumda örgütlerin de dikkat etmesi gereken uygulamalar vardır. Çalışanlara yaptıkları işin sonuçları hakkında geri bildirim vermek, işleri hakkında rahat karar verebilecekleri bir ortam sağlamak, istenen görevlerin açık ve anlaşılır olmasına özen göstermek örgütsel anlamda tükenmişliği önlemek için kullanılabilecek yöntemlerden bazılarıdır (Tunaboylu, 2015).

Bir örgüt olarak okul özelinde düşünülecek olursa yönetici ve öğretmenlerin işinden doyum sağlamasının yanı sıra stres ve tükenmişlikle de başa çıkabilmeleri okulların başarıya ulaşmasında önemli bir faktördür. Bunun yanı sıra okullarda demokratik bir ortamın olması, işgörenler arasında sosyal bütünleşmenin olması, işgörenlerin becerilerinin geliştirilmesi, güvenli ve sağlıklı mekânların oluşturulması işgörenlerin okula bağlılığına katkı sunmakta ve okulun bir üyesi olmaktan gurur duymalarını sağlamaktadır (Erdem, 2010).

\section{İş Yükü ile Tükenmişlik İlişkisi}

İş yükü ve iş kontrolünün iş özellikleri boyutuyla tükenmişliğin belirleyicileri arasında olduğu görülmektedir. Çalışanların iş yükü arttıkça tükenmişlik düzeyleri artarken işleri üzerindeki kontrolü yükseldikçe tükenmişlik düzeyleri azalmaktadır. Dolayısıyla tükenmişlik, bir anlamda iş yükü ve iş kontrolünün bir sonucuyken aynı zamanda bu iki 
değişken arasındaki etkileşim halinin de doğal bir sonucudur. Yüksek iş yüküne sahip çalışanlar, kendilerini bilgi, beceri ve öz kaynaklar açısından yetersiz görürler. Çalışanlar bu durumda zamanla kaygılanarak tükenmişlik yaşarlar. Tersi durumda, düşük iş yüküne sahip çalışanlar fazla çaba göstermelerine ihtiyaç olmadı̆̆ı için tükenmişlikleri de düşük olacaktır. Ancak, çalışanların iş yükleri çok düşük olduğunda sahip oldukları beceri ve yetenekleri kullanamamalarından kaynaklı bir miktar da olsa tükenmişlik görülebilir (Bolat, 2011).

Leiter’a (2003) göre bireyin sahip olduğu bilgi, beceri ve yetenekleri ile yaptığı iş arasındaki uyumsuzluk, bireyin işine yönelik sahip olduğu enerjiyi, aidiyet ve yeterlilik duygusunu azaltıcı bir etki yaratmakta ve tükenmişliğe neden olmaktadır. Tersi durumda ise ortaya çıkacak uyum, çalışanın işe bağlılığını artırmaktadır (akt. Budak ve Sürgevil, 2005).

Tükenmişliğin kaynaklarına bakıldığında kişisel olmaktan ziyade durumsal olduğu görülmektedir. Bu sebeple tükenmişliği önlemeye yönelik çözümler kişinin özünde değil çoğunlukla işin sosyal ortamında aranmalıdır (Maslach ve Leiter, 1997). Buradan yola çıkarak kişisel mücadele tekniklerinin yanı sıra işin sosyal ortamında yapılacak genel iyileştirmeler, çalışanlarda tükenmişliğin baş göstermesine daha kalıcı şekilde engel olacaktır.

$\mathrm{Bu}$ çalışmada iş yükü ile tükenmişlik arasındaki ilişki değerli görülerek sınıf öğretmenlerinin iş yükü algısı ve mesleki tükenmişlik düzeyleri araştırılıp bu iki olgu arasındaki ilişkinin ortaya çıkarılması planlanmaktadır. Bu bağlamda; resmi ilkokullarda görev yapan sınıf öğretmenlerinin iş yükü algısı ile mesleki tükenmişlikleri arasındaki ilişki düzeyinin belirlenmesi araştırmanın temel problemini oluşturmaktadır.

\section{Amaç}

$\mathrm{Bu}$ araştırmanın genel amacı, Türkiye'de Millî Eğitim Bakanlığına bağlı resmi ilkokullarda görev yapan sınıf öğretmenlerinin iş yükü algısı ile mesleki tükenmişlikleri arasındaki ilişki düzeyini belirlemektir. Buna yönelik aşağıdaki sorulara cevap aranmıştır.

1. Öğretmenlerin iş yükü algısı ve mesleki tükenmişlikleri ne düzeydedir?

2. Öğretmenlerin iş yükü algısı ve mesleki tükenmişlikleri,
a) Cinsiyet
b) Medeni durum
c) Yaş
d) Mesleki kıdemlerine göre anlamlı farklılık göstermekte midir?

3. İş yükü ile mesleki tükenmişlik arasında anlamlı bir ilişki var mıdır? 


\section{Yöntem}

$\mathrm{Bu}$ araştırmada nicel yöntem kullanılmıştır. İş yükü algısı ile mesleki tükenmişlik düzeyleri arasındaki ilişki belirlenmeye çalışıldığı için araştırma ilişkisel tarama modelindedir.

\section{Evren ve Örneklem}

Araştırmanın hedef evrenini Samsun ilinin merkezinde yer alan Atakum, Canik ve İlkadım ilçelerindeki resmi ilkokullarda görev yapan 1475 sınıf öğretmeni oluşturmaktadır. Atakum, Canik ve İlkadım ilçelerinde Millî Eğitim Bakanlığına bağlı toplam 97 ilkokul bulunmaktadır. Evren bilgilerine Samsun İl Millî Eğitim Müdürlüğünün 2017 yılı Temmuz ayı verileri temel teşkil etmiştir.

Örneklemdeki öğretmenler, hedef evreni temsil edecek şekilde üç ilçedeki resmi ilkokullardan tabakalı örnekleme yöntemi ile orantılı olarak belirlenmiştir. Araştırmanın örneklemini hedef evrenden seçilen 329 sinıf öğretmeni oluşturmaktadır. .05 anlamlılık düzeyinde 5000 evren için 357 örneklem yeterli görülmektedir (Büyüköztürk, Çakmak, Akgün, Karadeniz ve Demirel, 2016). Örneklem sayısı belirlenirken ilçelerden, okullardan ve öğretmenlerden araştırmaya etki edebilecek sayıda denek alınmasına dikkat edilmiştir.

Araştırmaya katılan öğretmenlere ilişkin kişisel değişkenler cinsiyet, medeni durum, yaş ve mesleki kıdem olarak belirlenmiştir. Örnekleme dâhil edilecek okul sayıları belirlenirken bir okuldan 8-12 civarı öğretmene ulaşılması temel alınmıştır. Araştırmanın örneklemi tabakalı orantılı örnekleme yöntemi ile belirlenmiştir. Araştırmaya dâhil edilen öğretmenlerin demografik bilgileri Tablo 1'de verilmiştir.

Tablo 1. Öğretmenlerin Demografik Bilgileri

\begin{tabular}{llcc}
\hline \multirow{2}{*}{ Cinsiyet } & & $F$ & $\%$ \\
\multirow{3}{*}{ Medeni durum } & Kadın & 194 & 59,0 \\
& Erkek & 135 & 41,0 \\
\cline { 2 - 4 } & Evli & 302 & 91,8 \\
Yaş & Bekâr & 27 & 8,2 \\
\cline { 2 - 4 } & $27-40$ yaş & 61 & 18,5 \\
& $41-50$ yaş & 205 & 62,3 \\
Mesleki Kidem & $51-64$ yaş & 63 & 19,1 \\
\cline { 2 - 4 } & $4-20$ yıl & 105 & 31,9 \\
& $21-30$ yıl & 181 & 55,0 \\
& $31-43$ yıl & 43 & 13,1 \\
& Total & 329 & 100,0 \\
\hline
\end{tabular}


Tablo 1'de görüldüğü gibi araştırmaya katılan öğretmenlerin \% 59'u kadın, \% 41'i erkek; \% 91,8'i evli, \% 8,2'si bekâr; \% 18,5'i 27-40 yaş, \% 62,3’ü 41-50 yaş ve \% 19,1’i 51-64 yaş aralığında olup \% 31,9’u 4-20 yıl, \% 55,0’i 21-30 yıl ve \% 13,1'i 31-43 y1l aralığında mesleki kıdeme sahiptirler.

\section{Veri Toplama Aracı}

Araştırmanın veri toplama aracı "Kişisel Bilgi Formu”, "Öğretmenlerde İş Yükü Algısı Ölçeği”” ve “Öğretmen Mesleki Tükenmişlik Ölçeği” olmak üzere üç bölümden oluşmaktadır. İlk bölümde katılımcıların cinsiyet, medeni durum, yaş ve mesleki kıdemlerine ilişkin dört sorunun yer aldığı kişisel bilgi formu bulunmaktadır.

Öğretmenlerin iş yükü algısını ölçmek için Keleş Ay’ın (2010) geliştirdiği tek boyutlu “Öğretmenlerde İş Yükü Algısı Ölçeği” kullanılmıştır. Bunun için gerekli izin Keleş Ay’dan e-mail aracılığı ile alınmıştır. Keleş Ay, ölçeği geliştirirken Aycan ve Eskin tarafından 2005 y1lında Türkçeye uyarlanan İş Yükü Ölçeği maddelerinden esinlenmiştir. 17 maddeden oluşan ölçek 136 öğretmeni kapsayan pilot uygulamadan sonra yapılan faktör analizi sonucu 6 madde elenerek 11 maddelik tek boyutlu ölçek oluşturulmuştur. Öğretmenlerde İş Yükü Algısı Ölçeği’nin açıkladığı toplam varyans \%54,16'dır. Ölçeğin tümüne ilişkin CronbachAlfa güvenirlik katsayısı .86'dır. Ölçeğin faktör yük değerleri .55 ile .69 arasında değişmektedir.

Öğretmenlerde İş Yükü Algısı Ölçeği’nde likert tipi beşli dereceleme seçenekleri kullanılmıştır. $\mathrm{Bu}$ çalışmada derecelendirme "1-Hiç katılmıyorum, 2-Katılmıyorum, 3-Kısmen katılıyorum, 4-Katılıyorum, 5-Tamamen katılıyorum” şeklinde değerlendirilmiştir. Ölçekten elde edilen tek bir toplam puan aritmetik ortalama ve frekans değerleri kullanılarak yorumlama yapılmıştır.

Sınıf öğretmenlerinin mesleki tükenmişliklerini ölçmek için Yellice Yüksel, Kaner ve Şekercioğlu (2008) tarafından geliştirilen 26 maddelik “Öğretmen Mesleki Tükenmişlik Ölçeği” kullanılmıştır. Ölçek izni e-mail aracılığı ile alınmıştır. ÖMTÖ’nün yapı geçerliği ve faktör analizi Yellice Yüksel ve arkadaşları tarafından yapılmıştır. Gerekli analizler sonucunda ölçek 4 faktör ve 26 maddeden oluşmuştur. Faktörler sırasıyla; "Mesleğe ilişkin duygusal tükenmişlik ve başarısızlık”, "Öğrencilere duyarsızlaşma”, "Fiziksel ve duygusal tükenme" ile "Meslektaşlara ve yöneticilere duyarsızlaşma" şeklindedir. Maddelerin faktör yük değerleri .506 ile .841 arasında değişmektedir. ÖMTÖ’nün Cronbach alfa güvenirlik 
katsayılarının .80 ile 92 arasında değiştiği görülmüştür. ÖMTÖ’nün aynılık geçerliğini incelemek amacıyla ÖMTÖ ve Türkiye’de benzer araştırmalarda sıkça kullanılan Maslach Tükenmişlik Envanteri aynı bireylere birlikte uygulanmıştır. Bu uygulama sonucunda ÖMTÖ ve Maslach Tükenmişlik Envanterinin benzer yapıları ölçtüğü ve sonuçlarının uyuştuğu belirlenmiştir.

$\mathrm{Bu}$ çalışmada ÖMTÖ derecelendirme seçenekleri “1-Hiç katılmıyorum, 2-Katılmıyorum, 3-Kısmen kat1lıyorum, 4-Katılıyorum, 5-Tamamen katılıyorum” şeklinde yapılmıştır. Cevaplardan elde edilen puanlar tek bir toplam puanla değerlendirilmektedir. ÖMTÖ’den alınan yüksek puan yüksek mesleki tükenmişliği, düşük puan ise düşük mesleki tükenmişliği ifade etmektedir.

\section{Verilerin Toplanması ve Analizi}

Ölçeklerin Samsun ilinin Atakum, Canik ve İlkadım ilçelerindeki ilkokullarda uygulanması için Samsun İl Millî Eğitim Müdürlüğünden gerekli izinler alınmıştır. Veri toplama aracı bizzat araştırmacı tarafından öğretmenlere kapalı zarf içinde elden verilmiş ve yine kapalı zarf içinde elden alınmıştır. Ölçeklerin öğretmenlere uygulanması 3 hafta gibi kısa bir sürede tamamlanmıştır.

Araştırmada elde edilen veriler istatistik programı kullanılarak analiz edilmiştir. Verilerin analizi için ilk aşamada değişkenlerin frekans dağılımlarına bakılmıştır. Elde edilen verilerin analizi sırasında bağımlı değişkenlerin diğer değişkenlere göre homojenlik gösterip göstermediği homojenlik testi ile test edilmiştir. Değişkenlerin homojen dağıldığı durumlarda parametrik testler (t-testi ve ANOVA) kullanılmıştır. Değişkenlerin homojen dağılım göstermediği durumlarda ya da denek sayı farklarının çok yüksek olması durumunda parametrik olmayan testler (Mann-Whitney U testi ve Kruskal Wallis testi) kullanılmıştır (Kilmen, 2015).

Sınıf öğretmenlerinin iş yükü algısı ile mesleki tükenmişlik düzeylerinin cinsiyete göre farklılaşıp farklılaşmadığı t-testiyle, medeni duruma göre farklılaşıp farklılaşmadığ 1 (denek sayısında farkın yüksek olması nedeniyle) Mann-Whitney U testiyle, yaş ve mesleki kıdeme göre farklılaşıp farklılaşmadığı ANOVA ve Kruskal Wallis testiyle analiz edilmiştir. Anlamlı farklılık çıkan alt boyutları belirlemek amacıyla Tukey HSD testinden yararlanılmıştır. İş yükü algısı ile mesleki tükenmişlik arasındaki ilişki düzeyini bulmak için ise Pearson korelasyon analizi yapılmıştır. 
Pearson korelasyonu analizinden çıkan ilişki 0 - 0,29 arası düşük, 0,30 - 0,69 arası orta, 0,70 ve üstü yüksek düzey olarak değerlendirilmektir (Roscoe, 1975, akt. Büyüköztürk, Çokluk ve Köklü, 2010). Ölçeklerin değerlendirilmesinde likert tipi beşli dereceleme ölçeği kullanılmıştır. Ölçeklerin değerlendirilmesine ilişkin ölçek baremine Tablo 2'de yer verilmiştir.

Tablo 2. Ölçek Baremi

\begin{tabular}{ccl}
\hline Puan Aralığı & Verilen Puan & \multicolumn{1}{c}{ Seçenekler } \\
\hline $1.00-1.80$ arası görüşler & 1 & Hiç katılmıyorum \\
$1.81-2.60$ arası görüşler & 2 & Katılmıyorum \\
$2.61-3.40$ arası görüşler & 3 & Kismen katılıyorum \\
$3.41-4.20$ arası görüşler & 4 & Katılıyorum \\
$4.21-5.00$ arası görüşler & 5 & Tamamen katılıyorum \\
\hline
\end{tabular}

Tablo 2’de görüldüğü üzere ölçekte 1.00-1.80 puan aralığ1 "Hiç katılmıyorum”, 1.81-2.60 puan aralığ1 “Katılmıyorum”, 2.61-3.40 puan aralığ1 "Kısmen kat1liyorum”, 3.41-4.20 puan aralığı "Katılıyorum” ve 4.21-5.00 puan aralığı "Tamamen katılıyorum" olarak değerlendirilmektedir.

\section{Bulgular}

$\mathrm{Bu}$ bölümde araştırma problemlerine ilişsin olarak elde edilen bulgulara yer verilmiştir. Elde edilen bulgulara dayalı olarak tablolar, açıklamalarla birlikte desteklenmiştir. Öğretmenlerin iş yükü algıları ile mesleki tükenmişlik toplam ve alt boyutlarına ilişkin aritmetik ortalama ve standart sapma değerleri Tablo 3’te verilmiştir.

Tablo 3. Öğretmenlerin İş Yükü Alglları ile Mesleki Tükenmişlik Toplam ve Alt Boyutlara İlişkin Bulgular

\begin{tabular}{|c|c|c|c|}
\hline & $\mathrm{n}$ & $\overline{\mathrm{x}}$ & S \\
\hline İş yükü algısı & 329 & 2,5618 & .61740 \\
\hline Toplam mesleki tükenmişlik & 329 & 2,0060 & .65742 \\
\hline \multirow{2}{*}{$\begin{array}{l}\text { Mesleğe ilişkin duygusal } \\
\text { tükenmişlik ve başarısızlık } \\
\text { Meslektaşlara ve yöneticilere } \\
\text { duyarsızlaşma }\end{array}$} & 329 & 2,2054 & .86879 \\
\hline & 329 & 2,0693 & .76545 \\
\hline Öğrencilere duyarsızlaşma & 329 & 1,9240 & .73481 \\
\hline Fiziksel ve duygusal tükenmişlik & 329 & 1,8432 & 69794 \\
\hline
\end{tabular}


Tablo 3’te öğretmenlerin iş yükü algıları ile mesleki tükenmişlik toplam ve alt boyutlarına bakıldığında öğretmenlerin iş yüklerinin düşük düzeyde olduğu $(\bar{x}=2,56)$ ve aynı zamanda mesleki tükenmişliklerinin de düşük düzeyde olduğu $(\bar{x}=2,01)$ anlaşılmaktadır. Mesleki tükenmişliğin alt boyutları arasında öğretmenler en az fiziksel ve duygusal tükenmişliğe $(\bar{x}=1,84)$, en fazla ise mesleğe ilişkin duygusal tükenmişlik ve başarısızlığa $(\bar{x}=2,21)$ katılmışlardır. Öğretmenler öğrencilere duyarsızlaşma alt boyutu $(\bar{x}=1,92)$ ile meslektaşlara ve yöneticilere duyarsızlaşma alt boyutuna $(\bar{x}=2,07)$ "Katılmıyorum" düzeyinde katılım göstermişlerdir. Bu bulgulara göre öğretmenlerin, mesleki tükenmişliğin tüm alt boyutlarına “Katılmıyorum” düzeyinde katılım gösterdikleri anlaşılmaktadır. Öğretmenlerin İş Yükü Algısı Ölçeği'nde en fazla ve en az katıldıkları maddelere Tablo 4’te yer verilmiştir.

Tablo 4. Öğretmenlerin Işs Yükü Algısı Ölçeği’nde En Fazla ve En Az Katıldıkları Maddeler

\begin{tabular}{lccc}
\hline Maddeler & $\mathrm{n}$ & $\overline{\mathrm{x}}$ & $\mathrm{S}$ \\
\hline $\begin{array}{l}\text { İ8. Rehber öğretmene öğrencilerin kişisel bilgileri ile ilgili işlerde } \\
\text { destek oluyorum. }\end{array}$ & 329 & 3,7052 & 1,12130 \\
$\begin{array}{l}\text { İ9. Dinlenme aralarımı (öğrencilerin sorularını yanıtlama, nöbet vb. } \\
\text { sebeplerle) kendime ayıramıyorum. }\end{array}$ & 329 & 3,3374 & 1,21669 \\
$\begin{array}{l}\text { İ5. Okul içindeki kimi çalışmalar gece geç saatlere kadar okulda } \\
\text { çalışmamı gerektiriyor. }\end{array}$ & 329 & 1,5897 & .88277 \\
$\begin{array}{l}\text { İ6. Yaz tatilinde de gerek duyulduğunda okula } \\
\text { çağırılıyorum. }\end{array}$ & 329 & 1,5684 & .89496 \\
\hline
\end{tabular}

Tablo 4’te görüldüğü üzere öğretmenler iş yükü algısı ölçeğinde en fazla “"Rehber öğretmene öğrencilerin kişisel bilgileri ile ilgili işlerde destek oluyorum.” ( $\bar{x}=3,71)$ ve "Dinlenme aralarımı (öğrencilerin sorularını yanıtlama, nöbet vb. sebeplerle) kendime ayıramıyorum." ( $\bar{x}=3,34)$ ifadelerine katılmışlardır. Öğretmenler aynı ölçekte en az "Yaz tatilinde de gerek duyulduğunda okula çağırılıyorum." ( $\bar{x}=1,57)$ ve "Okul içindeki kimi çalışmalar gece geç saatlere kadar okulda çalışmamı gerektiriyor." $(\bar{x}=1,59)$ ifadelerine "Hiç katılmıyorum” düzeyinde katılım göstermişlerdir. Öğretmenlerin Öğretmen Mesleki Tükenmişlik Ölçeği'nde en fazla ve en az katılım gösterdikleri maddelere Tablo 5'te yer verilmiştir. 
YYÜ Eğitim Fakültesi Dergisi (YYU Journal of Education Faculty), 2020; 17(1):926-958,http://efdergi.yyu.edu.tr,

doi: 10.33711/yyuefd.751859

Araștırma Makalesi

ISSN: 1305-2020

Tablo 5. Öğretmenlerin ÖMTÖ'de En Fazla ve En Az Katıldıkları Maddeler

\begin{tabular}{lccc}
\hline Maddeler & $\mathrm{n}$ & $\overline{\mathrm{x}}$ & $\mathrm{S}$ \\
\hline T24. Yöneticiler, öğretmen olarak çabalarımı takdir etmiyorlar. & 329 & 2,5198 & 1,12635 \\
\hline T14. Bütün gün öğrencilerle uğraşmak beni çok yıpratıyor. & 329 & 2,5046 & 1,16901 \\
\hline T20. Ders saatleri bir türlü bitmek bilmiyor. & 329 & 1,5684 & .71719 \\
\hline T22. Meslektaşlarımla sık sık tartışıyorum. & 329 & 1,5593 & .82102 \\
\hline
\end{tabular}

Tablo 5’te görüldüğü gibi öğretmenler Öğretmen Mesleki Tükenmişlik Ölçeği’’nde en fazla "Yöneticiler, öğretmen olarak çabalarımı takdir etmiyorlar." ( $\bar{x}=2,52)$ ve "Bütün gün öğrencilerle uğraşmak beni çok yıpratıyor." ( $\bar{x}=2,50)$ ifadelerine katılmışlardır. Öğretmenler en az "Meslektaşlarımla sık sık tartışıyorum." ( $\bar{x}=1,56)$ ve "Ders saatleri bir türlü bitmek bilmiyor" ( $\bar{x}=1,57)$ ifadelerine "Hiç katılmıyorum” düzeyinde katılım göstermişlerdir. Öğretmenlerin cinsiyet değişkenine göre iş yükü ve mesleki tükenmişlik düzeyleri Tablo 6’da verilmiştir.

Tablo 6. Cinsiyet Değişkenine Göre Öğretmenlerin Işs Yükü ve Mesleki Tükenmişlik Düzeyleri

\begin{tabular}{|c|c|c|c|c|c|c|c|}
\hline & & $n$ & $\overline{\mathrm{x}}$ & S & $\mathrm{t}$ & $\mathrm{df}$ & $\mathrm{p}$ \\
\hline \multirow{2}{*}{ İş yükü } & Kadın & 194 & 2,6111 & .61765 & 1,742 & 327 & .083 \\
\hline & Erkek & 135 & 2,4909 & .61238 & 1,744 & 289,977 & .082 \\
\hline \multirow{2}{*}{$\begin{array}{l}\text { Toplam mesleki } \\
\text { tükenmişlik }\end{array}$} & Kadın & 194 & 1,9939 & .65202 & -.400 & 327 & .689 \\
\hline & Erkek & 135 & 2,0232 & .66715 & -.398 & 284,167 & .691 \\
\hline \multirow{2}{*}{$\begin{array}{l}\text { Mesleğe ilişkin } \\
\text { duygusal tükenmişlik } \\
\text { ve başarısızlık }\end{array}$} & Kadın & 194 & 2,1664 & .86956 & -.975 & 327 & .330 \\
\hline & Erkek & 135 & 2,2614 & .86783 & -.975 & 288,778 & .330 \\
\hline \multirow{2}{*}{$\begin{array}{l}\text { Meslektaşlara ve } \\
\text { yöneticilere } \\
\text { duyarsılaşma }\end{array}$} & Kadın & 194 & 1,9411 & .73169 & .505 & 327 & .614 \\
\hline & Erkek & 135 & 1,8995 & .74130 & .504 & 286,011 & .615 \\
\hline \multirow{2}{*}{$\begin{array}{l}\text { Öğrencilere } \\
\text { duyarsızlaşma }\end{array}$} & Kadın & 194 & 1,8667 & .70333 & .731 & 327 & .466 \\
\hline & Erkek & 135 & 1,8095 & .69132 & .733 & 291,540 & .464 \\
\hline \multirow{2}{*}{$\begin{array}{l}\text { Fiziksel ve duygusal } \\
\text { tükenmişlik }\end{array}$} & Kadın & 194 & 2,0041 & .73912 & $-1,858$ & 327 & .064 \\
\hline & Erkek & 135 & 2,1630 & .79520 & $-1,834$ & 274,633 & .068 \\
\hline
\end{tabular}

Tablo 6’da görüldüğü gibi cinsiyet değişkenine göre öğretmenlerin hem iş yükü algıları hem de mesleki tükenmişlikleri anlamlı farklılık göstermemektedir ( $\mathrm{p}>.05)$. Sınıf öğretmenlerinin medeni durum değişkenine göre iş yükü ve mesleki tükenmişlik düzeyleri Tablo 7’de verilmiştir. 
YYÜ Eğitim Fakültesi Dergisi (YYU Journal of Education Faculty), 2020; 17(1):926-958,http://efdergi.yyu.edu.tr,

doi: 10.33711/yyuefd.751859

Araștırma Makalesi

ISSN: 1305-2020

Tablo 7. Medeni Durum Değişkenine Göre Öğretmenlerin İş Yükü ve Mesleki Tükenmişlik Düzeyleri

\begin{tabular}{|c|c|c|c|c|c|c|}
\hline & İş yükü & $\begin{array}{l}\text { Toplam } \\
\text { mesleki } \\
\text { tükenmişlik }\end{array}$ & $\begin{array}{c}\text { Mesleğe } \\
\text { ilişkin } \\
\text { duygusal } \\
\text { tükenmiş̧lik ve } \\
\text { başarısızlık } \\
\end{array}$ & $\begin{array}{c}\text { Öğrencilere } \\
\text { duyarsızlaşma }\end{array}$ & $\begin{array}{l}\text { Fiziksel ve } \\
\text { duygusal } \\
\text { tükenmişlik }\end{array}$ & $\begin{array}{l}\text { Meslektaşlara } \\
\text { ve yöneticilere } \\
\text { duyarsılaşma }\end{array}$ \\
\hline Mann-Whitney U & 3583,00 & 3636,50 & 3212,000 & 4000,500 & 4064,00 & 3869,000 \\
\hline Wilcoxon W & 3961,00 & 49389,5 & 48965,000 & 49753,500 & 4442,00 & 49622,000 \\
\hline Z & $-1,044$ & -.931 & $-1,830$ & -.162 & -.028 & -.441 \\
\hline $\mathrm{P}$ & .296 & .352 & .067 & .871 & .978 & 659 \\
\hline
\end{tabular}

Tablo 7’de görüldüğü gibi medeni durum değişkenine göre öğretmenlerin hem iş yükü algıları hem de mesleki tükenmişlikleri anlamlı düzeyde farklılaşmamaktadır ( $>$ >.05). Mesleki kıdeme göre iş yükü ve mesleki tükenmişlik düzeyleri Tablo 8'de verilmiştir.

Tablo 8. Mesleki Kıdem Değişkenine Göre Öğretmenlerin İş Yükü ve Mesleki Tükenmişlik Düzeyleri

\begin{tabular}{|c|c|c|c|c|c|c|}
\hline & & $\begin{array}{l}\text { Kareler } \\
\text { Toplamı }\end{array}$ & $\mathrm{df}$ & $\begin{array}{l}\text { Ortalama } \\
\text { Kare }\end{array}$ & $\mathrm{F}$ & $\mathrm{p}$ \\
\hline \multirow{3}{*}{ İş yükü } & Gruplar Aras1 & .610 & 2 & .305 & .800 & .450 \\
\hline & Gruplar İçi & 124,418 & 326 & .382 & & \\
\hline & Toplam & 125,028 & 328 & & & \\
\hline \multirow{3}{*}{ Toplam mesleki tükenmişlik } & Gruplar Aras1 & 1,437 & 2 & .718 & 1,669 & .190 \\
\hline & Gruplar İçi & 140,325 & 326 & .430 & & \\
\hline & Toplam & 141,762 & 328 & & & \\
\hline \multirow{3}{*}{$\begin{array}{l}\text { Mesleğe ilişkin } \\
\text { duygusal tükenmişlik } \\
\text { ve başarısızlık }\end{array}$} & Gruplar Aras1 & 3,073 & 2 & 1,537 & 2,049 & .131 \\
\hline & Gruplar İçi & 244,498 & 326 & .750 & & \\
\hline & Toplam & 247,571 & 328 & & & \\
\hline \multirow{3}{*}{$\begin{array}{l}\text { Öğrencilere } \\
\text { duyarsızlaşma }\end{array}$} & Gruplar Aras1 & 3,173 & 2 & 1,586 & 2,974 & .053 \\
\hline & Gruplar İçi & 173,927 & 326 & .534 & & \\
\hline & Toplam & 177,100 & 328 & & & \\
\hline \multirow{3}{*}{$\begin{array}{l}\text { Fiziksel ve duygusal } \\
\text { tükenmişlik }\end{array}$} & Gruplar Arası & 1,656 & 2 & .828 & 1,707 & .183 \\
\hline & Gruplar İçi & 158,117 & 326 & .485 & & \\
\hline & Toplam & 159,773 & 328 & & & \\
\hline \multirow{3}{*}{$\begin{array}{l}\text { Meslektaşlara ve } \\
\text { yöneticilere } \\
\text { duyarsılaşma } \\
\end{array}$} & Gruplar Arası & .185 & 2 & .093 & .157 & .854 \\
\hline & Gruplar İçi & 191,995 & 326 & .589 & & \\
\hline & Toplam & 192,180 & 328 & & & \\
\hline
\end{tabular}

Tablo 8'de görüldüğü üzere öğretmenlerin hem iş yükü algıları hem de mesleki tükenmişlikleri mesleki kıdem değişkenine göre farklılaşmamaktadır ( $\mathrm{p}>.05)$. Yaş değişkeni iş yükü algısına göre homojenliği sağlarken mesleki tükenmişlik algısına göre homojenliği sağlamamaktadır. Bu yüzden yaş değişskenine göre iş yükü düzeyine bakmak için ANOVA, mesleki tükenmişlik toplam ve alt boyutları için non-parametrik test olan Kruskal Wallis H testi yapılmıştır. Öğretmenlerin yaş değişkenine göre iş yükü algıları Tablo 9’da verilmiştir. 
YYÜ Eğitim Fakültesi Dergisi (YYU Journal of Education Faculty), 2020; 17(1):926-958,http://efdergi.yyu.edu.tr,

Tablo 9. Yaş Değisskenine Göre Öğretmenlerin İş Yükü Algllarl

\begin{tabular}{llccccc}
\hline & & $\begin{array}{c}\text { Kareler } \\
\text { Toplamı }\end{array}$ & df & $\begin{array}{c}\text { Ortalama } \\
\text { Kare }\end{array}$ & F & p \\
\hline \multirow{4}{*}{ İş yükü } & Gruplar Arası & 1,141 & 2 & .571 & 1,502 & .224 \\
& Gruplar İçi & 123,887 & 326 & .380 & & \\
& Toplam & 125,028 & 328 & & & \\
\hline
\end{tabular}

Tablo 9’da görüldüğü üzere öğretmenlerin iş yükü algıları yaş değişkenine göre farklılaşmamaktadır ( $\mathrm{p}>.05$ ). Sınıf öğretmenlerinin yaş değişkenine göre mesleki tükenmişlik toplam ve alt boyutları Tablo 10’da verilmiştir.

Tablo 10. Yaş Değişkenine Göre Ögrretmenlerin Mesleki Tükenmişlik Toplam ve Alt Boyutları

\begin{tabular}{cccccc}
\hline & $\begin{array}{c}\text { Mesleğe ilişkin } \\
\text { duygusal tükenmişlik } \\
\text { ve başarısızlı }\end{array}$ & $\begin{array}{c}\text { Öğrencilere } \\
\text { duyarsızlaşma }\end{array}$ & $\begin{array}{c}\text { Fiziksel ve } \\
\text { duygusal } \\
\text { tükenmişlik }\end{array}$ & $\begin{array}{c}\text { Meslektaşlara } \\
\text { ve yöneticilere } \\
\text { duyarsızlaşma }\end{array}$ & $\begin{array}{c}\text { Toplam } \\
\text { mesleki } \\
\text { tükenmişlik }\end{array}$ \\
\hline Ki Kare & 10,277 & 10,152 & 7,663 & 8,876 & 11,554 \\
df & 2 & 2 & 2 & 2 & 2 \\
p & .006 & .006 & .022 & .012 & .003 \\
\hline
\end{tabular}

Tablo 10’da görüldüğü gibi öğretmenlerin mesleki tükenmişlikleri yaş değişkenine göre anlamlı bir farklılık göstermektedir $(p<.05)$. Buna göre sıra değerleri Tablo 11'de verilmiştir.

Tablo 11. Yaş Değişkenine Göre Öğretmenlerin Mesleki Tükenmişlik Toplam ve Alt Boyutlart Stra Değerleri

\begin{tabular}{lccc}
\hline & Yaş & $\mathrm{n}$ & Sira Ortalaması \\
\hline \multirow{3}{*}{ Toplam mesleki tükenmişlik } & $27-40$ yaş & 61 & 153,07 \\
& $51-64$ yaş & 205 & 178,09 \\
& & 63 & 133,97 \\
\hline Mesleğe ilişkin & $27-40$ yaş & 61 & 154,36 \\
duygusal tükenmişlik & $41-50$ yaş & 205 & 177,25 \\
ve başarısızlık & $51-64$ yaş & 63 & 135,45 \\
\cline { 2 - 4 } & $27-40$ yaş & 61 & 163,57 \\
Öğrencilere & $41-50$ yaş & 205 & 175,54 \\
duyarsizlaşma & $51-64$ yaş & 63 & 132,09 \\
\cline { 2 - 4 } & $27-40$ yaş & 61 & 175,93 \\
Fiziksel ve duygusal & $41-50$ yaş & 205 & 139,48 \\
tükenmişlik & $51-64$ yaş & 63 & 140,92 \\
\cline { 2 - 4 } & $27-40$ yaş & 61 & 176,91 \\
Meslektaşlara ve & $41-50$ yaş & 205 & 149,55 \\
yöneticilere & $51-64$ yaş & 63 & \\
duyarsızlaşma & & & \\
\hline
\end{tabular}


Tablo 11'de sıra değerlere bakıldığında toplam mesleki tükenmişlikte en üst sırada 41-50 yaş grubundaki öğretmenler $(\mathrm{SO}=178,09)$, sonra 27-40 yaş grubundaki öğretmenler ( $\mathrm{SO}=153,07)$, daha sonra 51-64 yaş grubundaki öğretmenler $(\mathrm{SO}=133,97)$ yerini almaktadır. Öğretmenlerin iş yükü algısı ile mesleki tükenmişlik düzeyleri arasındaki ilişki Tablo 12’de verilmiştir.

Tablo 12. Öğretmenlerin İş Yükü Algısı ile Mesleki Tükenmişlik Düzeyleri Arasındaki İlişki

\begin{tabular}{|c|c|c|c|c|c|c|c|}
\hline & & İş yükü & $\begin{array}{c}\text { Mesleğe } \\
\text { ilişkin } \\
\text { duygusal } \\
\text { tükenmişlik } \\
\text { ve } \\
\text { başarısızlık }\end{array}$ & $\begin{array}{c}\text { Öğrencilere } \\
\text { duyarsızlaşma }\end{array}$ & $\begin{array}{c}\text { Fiziksel ve } \\
\text { duygusal } \\
\text { tükenmişlik }\end{array}$ & $\begin{array}{l}\text { Meslektaşlara } \\
\text { ve yöneticilere } \\
\text { duyarsızlaşma }\end{array}$ & $\begin{array}{c}\text { Toplam } \\
\text { mesleki } \\
\text { tükenmişlik }\end{array}$ \\
\hline \multirow{2}{*}{ İş yükü } & $\mathrm{r}$ & 1 & $.312^{* *}$ & $.355^{* *}$ & $.402^{* *}$ & $.369^{* *}$ & $.415^{* *}$ \\
\hline & $\mathrm{p}$ & & .000 & .000 & .000 & .000 & .000 \\
\hline \multirow{2}{*}{$\begin{array}{l}\text { Toplam mesleki } \\
\text { tükenmişlik }\end{array}$} & $\mathrm{r}$ & $.415^{* *}$ & $.879^{* *}$ & $.896^{* *}$ & $.912^{* *}$ & $.701^{* *}$ & 1 \\
\hline & $\mathrm{p}$ & .000 & .000 & .000 & .000 & .000 & \\
\hline \multirow{2}{*}{$\begin{array}{l}\text { Mesleğe ilişkin } \\
\text { duygusal } \\
\text { tükenmişlik ve } \\
\text { başarısızlık }\end{array}$} & $\mathrm{r}$ & $.312^{* *}$ & 1 & $.700^{* *}$ & $.732^{* *}$ & $.461^{* *}$ & $.879^{* *}$ \\
\hline & $\mathrm{p}$ & .000 & & .000 & .000 & .000 & .000 \\
\hline \multirow{2}{*}{$\begin{array}{l}\text { Öğrencilere } \\
\text { duyarsızlaşma }\end{array}$} & $\mathrm{r}$ & $.355^{* *}$ & $.700^{* *}$ & 1 & $.804^{* *}$ & $.518^{* *}$ & $.896^{* *}$ \\
\hline & $\mathrm{p}$ & .000 & .000 & & .000 & .000 & .000 \\
\hline \multirow{2}{*}{$\begin{array}{l}\text { Fiziksel ve } \\
\text { duygusal } \\
\text { tükenmişlik }\end{array}$} & $\mathrm{r}$ & $.402^{* *}$ & $.732^{* *}$ & $.804^{* *}$ & 1 & $.551^{* *}$ & $.912^{* *}$ \\
\hline & $\mathrm{p}$ & .000 & .000 & .000 & & .000 & .000 \\
\hline \multirow{2}{*}{$\begin{array}{l}\text { Meslektaşlara } \\
\text { ve yöneticilere } \\
\text { duyarsızlaşma }\end{array}$} & $\mathrm{r}$ & $.369^{* *}$ & $.461^{* *}$ & $.518^{* *}$ & $.551^{* *}$ & 1 & $.701^{* *}$ \\
\hline & $\mathrm{p}$ & .000 & .000 & .000 & .000 & & .000 \\
\hline
\end{tabular}

Tablo 12'de görüldüğü gibi iş yükü algısı ile mesleki tükenmişlik toplam puanı $(\mathrm{r}=.42)$ arasında anlamlı $(\mathrm{p}<.001)$, pozitif ve orta düzeyde bir ilişki olduğu görülmektedir. İş yükü algısı ile mesleki tükenmişlik alt boyutları arasında da anlamlı $(\mathrm{p}<.001)$, pozitif ve orta düzeyde bir ilişki vardır. İş yükü algısı ile mesleki tükenmişliğin dört alt boyutu arasındaki en yüksek ilişki fiziksel ve duygusal tükenmişlik $(r=.40)$ alt boyutunda görülmüştür. İş yükü algısı ile mesleki tükenmişliğin dört alt boyutu arasındaki en düşük ilişki ise mesleğe ilişkin duygusal tükenmişlik ve başarısızlık $(r=.31)$ alt boyutunda görülmüştür. Toplam mesleki tükenmişlik ile en fazla ilişki gösteren alt boyutun fiziksel ve duygusal tükenmişlik $(r=.91)$ olduğu görülmektedir. Sonra sırasıyla öğrencilere duyarsızlaşma $(r=.90)$, mesleğe ilişkin duygusal tükenmişlik ve başarısızlık $(r=.88)$ ve son olarak meslektaşlara ve yöneticilere duyarsızlaşma $(r=.70)$ gelmektedir. 


\section{Sonuç, Tartışma ve Öneriler}

Araştırma sonucunda öğretmenlerin iş yüklerinin ağır olmadığı (düşük düzeyde olduğu) anlaşılmıştır. Bu araştırmanın sonucu Keleş Ay’ın (2010) çalışmasında öğretmenlerin iş yükü algısının orta düzeyde olduğu sonucuyla uyuşmamaktadır. Öğretmenlerin iş yükü algılarının düşük düzeyde olmasının sebebi son yıllarda yeni dersliklerin yapılmasıyla derslik başına düşen öğrenci sayısının azalması, FATİH projesi vb. etkenlerle okullarda teknoloji kullanımının her geçen yıl artmasıyla derslerin dijital ortamlarda işlenebilmesi ve evrakların dijital olarak kısa sürede hazırlanabilmesi olabilir. Keleş Ay’ın (2010) çalışmasından bu yana geçen 10 yılda ülkemizde eğitim alanında yapılan fiziksel ve teknolojik iyileştirmeler, öğretmen sayısının artması ve Keleş Ay'ın çalışmasına sınıf öğretmenlerinin yanı sıra ilköğretim okullarında görev yapan branş öğretmenlerini de dâhil etmesi bu iki çalışmanın sonuçlarının örtüşmemesine kaynak gösterilebilir (Milli Eğitim Bakanlığı [MEB], 2018).

Öğretmenler iş yükü algısında en fazla “"Rehber öğretmene öğrencilerin kişisel bilgileri ile ilgili işlerde destek oluyorum.” ve "Dinlenme aralarımı (öğrencilerin sorularını yanıtlama, nöbet vb. sebeplerle) kendime ayıramıyorum." ifadelerine katılmışlardır. Bunun sebebi sınıf öğretmenlerinin branş öğretmenlerine oranla öğrencileriyle daha çok vakit geçirdiği için onlara ait kişisel ve ailevi bilgilere daha çok sahip olmaları, dolayısıyla rehber öğretmenle ortak çalışma ihtiyacı doğması olabilir. Dinlenme aralarını kendilerine ayıramadıklarını ifade eden öğretmenler öğrencilerin sorularını yanıtlama, nöbet tutma, fotokopi çekme, okul idaresinin talep ettiği kısa toplantılara katılma ve veli görüşmeleri gibi işleri mesleklerinin bir parçası olarak kabul edip benimseyerek bu işleri reddedilemez olarak görüyor olabilirler.

Öğretmenler iş yükü algısında en az "Yaz tatilinde de gerek duyulduğunda okula çağırılıyorum." ve "Okul içindeki kimi çalışmalar gece geç saatlere kadar okulda çalışmamı gerektiriyor." ifadelerine katılmışlardır. Öğretmenlerin yaz tatilinde okula çağırılmadığını ifade etmesinin sebebi tayin vb. başvurularda tatildeki öğretmenlerin evraklarını imzalamaları için tatil sonuna kadar sürelerinin olması ve başvuruların internet üzerinden alınarak okullarla gerekli iletişimin telefon ve elektronik posta aracılığıyla yapılmasına MEB tarafından imkân sağlanması olabilir. Diğer ifadeye en az katılmalarının sebebi ise sınıf öğretmenlerinin gece nöbeti tutulan pansiyonlu okullarda görev yapmamaları ve son y1llarda toplantı, seminer, hizmet içi eğitim vb. faaliyetlerin mesai saatleri içerisinde yapılmasına ilişkin MEB görüş yazılarının bulunması olabilir. 
Cinsiyet değişkenine göre öğretmenlerin iş yükü algıları anlamlı bir farklılık göstermemektedir. Bu sonuca göre öğretmenlerin kadın veya erkek olmaları iş yükü algılarını etkilememektedir. Bu veriler Ingvarson, Kleinhenz, Beavis, Barwick, Carthy ve Wilkinson (2005) ve Özyolcu (2015) verileri ile örtüşmekte ancak Halis (2010) verileri ile örtüşmemektedir. Halis (2010) verilerine bakıldığında erkek öğretmenlerin iş yükü algılarının kadın öğretmenlere göre daha fazla olduğu görülmektedir. Halis’in (2010) öğretmenlerle birlikte okul yöneticilerini de araştırmaya dâhil etmesi ve iş yükünü alt faktörlerden biri olarak göstermesine rağmen esasen iş güçlügünü araştırması bu çalışmadan farklı sonuçlar bulmasının sebebi olabilir.

Medeni durum değişkenine göre öğretmenlerin iş yükü algıları anlamlı bir farklılık göstermemektedir. Bu sonuca göre öğretmenlerin evli veya bekâr olmaları iş yükü algılarını etkilememektedir. Bu veriler Korkmazer (2018) verileri ile örtüşmekte ancak Halis (2010) verileri ile benzerlik göstermemektedir. Halis (2010) verilerine bakıldığında bu çalışmadan farklı olarak evli öğretmenlerin iş yükü algılarının bekâr öğretmenlere göre daha fazla olduğu anlaşılmaktadır. Bu araştırmanın sonuçları ile Halis’in (2010) çalışmasından elde ettiği verilerin örtüşmemesinin sebebi veri toplama araçlarının farklı olması ve Halis'in (2010) çalışmasına sınıf öğretmenlerinin yanı sıra \% 45 oranında branş öğretmenlerini de dâhil etmesi olabilir.

Mesleki kıdem değişkenine göre öğretmenlerin iş yükü algıları anlamlı bir farklılık göstermemektedir. Buna göre ne kadar süredir öğretmenlik yapıldığg öğretmenlerin iş yükü algılarını etkilememektedir. $\mathrm{Bu}$ araştırmanın sonucu, Kahveci’nin (2016) sağlık çalışanlarında iş yükünü araştırdığı çalışmasının sonuçları ile benzerlik göstermekte ancak Newhook’un (2012) Kanada'da öğretmenlerle yaptı̆̆ı çalışmanın sonuçları ile benzerlik göstermemektedir. Newhook'un (2012) araştırma sonuçlarına göre kıdem, kırsal veya kentsel yerleşkede görev yapmak ve cinsiyet faktörleri iş yükünü etkilemektedir. Ayrıca Bivona'nın (2002) çalışmasının verileri de bu çalışmanın verileri ile ters düşmektedir. Bivona'nın (2002) verilerine göre 10 yıldan daha az mesleki kıdeme sahip olan öğretmenler, en az 10 yıllık deneyime sahip olan öğretmenlerden daha ağır bir iş yüküne sahiptirler. Bivona bu sonucu, 10 yıldan daha az deneyime sahip olan öğretmenlerin ders tasarlamayı ve iyi bir sınıf yöneticisi olmayı öğrenme sürecinde olmalarına, boş zamanlarını işle ilgili etkinliklere harcamalarına ve pedagojik görevlerin zamanlarının büyük bir kısmını almasına bağlamaktadır. 
Yaş değişkenine göre öğretmenlerin iş yükü algıları anlamlı bir farklılık göstermemektedir. Bu sonuca göre öğretmenlerin genç, orta yaşlı ya da yaşlı olması iş yükü algılarını etkilememektedir. Bu sonuç, farklı bir iş alanındaki çalışanlarla yapılan iş yükü araştırmasının sonuçlarıyla uyum göstermektedir (Keser, 2006). Bu araştırmalardan farklı olarak Sellen (2016) çalışmasında 25 yaş altındaki öğretmenlerin haftada ortalama 51 saat, 60 yaş ve üzerindeki öğretmenlerin ise haftada ortalama 38 saat çalıştıklarını ortaya koymuştur.

Mesleki tükenmişlik toplam ve alt boyutlarına bakıldığında öğretmenlerin mesleki tükenmişliklerinin olmadığı (düşük düzeyde olduğu) anlaşılmaktadır. Bu araştırmanın sonucu Cerit (2008), Türkçarpar (2011), Ertürk ve Keçecioğlu (2012), Kılınç (2018) ve Törnük (2019) çalışmalarının sonuçlarıyla benzerlik göstermekte ancak Cemaloğlu ve Kayabaşı'nın (2007) çalışmasının sonuçlarıyla benzerlik göstermemektedir. Bu çalışmada öğretmenlerin mesleki tükenmişliklerinin düşük düzeyde olmasının sebebi, öğretmenlerin önceki yıllarda çok zaman harcayarak yaptıkları işleri günümüzde okullarda teknoloji kullanımının artmasıyla birlikte çok daha kısa sürede yapabilmeleri olabilir.

Türkiye’de 2017-2018 eğitim öğretim yılında ilköğretim düzeyinde derslik başına düşen öğrenci sayısının 24'e ve ilkokullarda öğretmen başına düşen öğrenci sayısının 17'ye kadar düşmesiyle öğretmenlerin iş yükü miktarının azalmasından dolayı tükenmişliklerinin düşük düzeyde olması olağan karşılanabilir (MEB, 2018). Bu çalışmanın sonuçlarından farklı sonuçların elde edildiği Cemaloğlu ve Kayabaşı'nın (2007) çalışmasında ortaya çıkan yüksek tükenmişliğin sebepleri arasında ders yükünün fazlalığg, sınıfların kalabalık olması, ekonomik sorunlar, meslek içi yükselmede adaletli olmayan ölçütler ve iş yükü fazlalığg gösterilmiştir.

Öğretmenler mesleki tükenmişlik alt boyutları arasında en fazla mesleğe ilişkin duygusal tükenmişlik ve başarısızlığa katılmışlardır. Bunun sebebi öğretmenlerin kendilerinde olan özelliklerin öğretmenlik haricindeki bir meslek için daha uygun olduğunu, imkânları olsa başka mesleklere yönelebileceklerini ve öğretmenlik mesleğinin onların beklentilerini karşılamadığını hissettiklerinden olabilir.

Öğretmenler mesleki tükenmişlik alt boyutları arasında en az fiziksel ve duygusal tükenmişliğe katılmışlardır. Bunun sebebi olarak, öğretmenlerin yaptıkları işin kendilerinde strese, öfkeye, bunalıma, fiziksel ve ruhsal hastalıklara neden olmadığını hissetmeleri gösterilebilir. 
Öğretmenler mesleki tükenmişlikte en fazla "Yöneticiler, öğretmen olarak çabalarımı takdir etmiyorlar." ve "Bütün gün öğrencilerle uğraşmak beni çok yıpratıyor." ifadelerine katılım göstermişlerdir. Bu durum öğretmenlerin çalışmalarının yöneticiler tarafından yeteri kadar takip edilmediğinden ve yöneticilerin öğretmenlerin sınıf içi uygulamalarından yeteri kadar haberdar olmadığından kaynaklanabilir. Okul yöneticilerinin milli eğitim müdürlükleriyle ilişkileri, veli ilişkileri, okulun fiziki donatım eksikliklerinin giderilmesi, toplantılar, evrak takibi, yazışmalar vb. meşguliyetleri düşünüldüğünde öğretmenlerin takdir edilmesi gereken çabalarını fark edebilecek kadar onlarla vakit geçiremeyebileceği de ihtimal dâhilindedir.

En fazla katıldıkları diğer ifadeye göre öğretmenlerin ders saatlerinde ve nöbet görevi gereği teneffüslerde bütün gün öğrencilerle ilgilenmek durumunda kalması, bu görevlerinde meydana gelebilecek bir olumsuzlukta idari anlamda sorumlu tutulmaları zamanla onları yıpratır hale gelebilir. Ayrıca okulda ders saatleri haricinde kalan zamanlarda öğretmenlerin dinlenmeye firsat bulamaması veya teneffüs zamanlarının yetersiz olması da öğretmenlerin ifadelerine kaynak teşkil edebilir.

Öğretmenler mesleki tükenmişlikte en az "Meslektaşlarımla sık sık tartışıyorum." ve "Ders saatleri bir türlü bitmek bilmiyor." ifadelerine katılmışlardır. Öğretmenlerin tartışma zemininde bulunmamalarının sebebi birbirlerini iyi anlamaları, ortak paydada buluşabilmeleri, öğretmenler odasını tartışma platformu değil dinlenip rahatlama yeri olarak görmeleri ve birbirlerinin haklarına saygı duymaları olabilir. Bunun yanı sıra birlikte hareket etmeyi gerektiren zümre toplantılarının da duruma katkısı olabilir. Öğretmenlerin diğer ifadeye genel olarak katılmamalarının sebebi ders saati içinde öğrencilerle samimi bir ortamda güzel ve verimli vakit geçirmeleri olabilir.

Öğretmenlerin mesleki tükenmişlik düzeyleri cinsiyet değişkenine göre anlamlı bir farklılık göstermemektedir. Bu sonuç öğretmenlerin kadın ya da erkek olmalarının mesleki tükenmişlik düzeylerini etkilemediğini göstermektedir. Bu veriler Hock (1985), Maslach ve arkadaşları (2001), Croom (2003), Naktiyok ve Karabey’in (2005) verileri ile benzerlik göstermekte olup Dere Çiftçi’nin (2015) verileri ile benzerlik göstermemektedir. Dere Çiftçi’nin (2015) çalışmasında erkek öğretmenlerin mesleki tükenmişlik puanlarının kadın öğretmenlerin puanlarından daha yüksek olduğu görülmektedir. Kış (2015) eğitim paydaşlarının tükenmişliğinde cinsiyet farklılığına ilişkin yaptığı meta-analiz çalışmasında cinsiyet değişkeninin tükenmişlik üzerinde önemsiz düzeyde etkili olduğunu tespit etmiştir. 
Öğretmenlerin mesleki tükenmişlik düzeyleri medeni durum değişkenine göre anlamlı düzeyde farklılaşmamaktadır. Bu sonuç öğretmenlerin evli ya da bekâr olmalarının mesleki tükenmişlik düzeylerini etkilemediğini göstermektedir. Bu veriler Otacığlu’nun (2008) verileriyle uyuşmakta olup Atlı'nın (2019) araştırma sonuçlarıyla uyuşmamaktadır. Atlı'nın (2019) 400 öğretmeni dâhil ettiği çalışmasına bakıldığında bekâr öğretmenlerin evli öğretmenlere göre tükenmişlik düzeylerinin daha yüksek olduğu görülmektedir.

Öğretmenlerin mesleki tükenmişlik düzeyleri mesleki kıdem değişkenine göre farklılaşmamaktadır. Bu veriler Yoğun Erçen'in (2007) verileri ile örtüşmekte ancak Dönmez'in (2018) verileri ile örtüşmemektedir. Dönmez'in (2018) çalışmasına bakıldığında 6-10 yıl mesleki kıdemi olan öğretmenlerin tükenmişlik düzeyleri 16 yıl ve üzeri mesleki kıdemi olan öğretmenlerden anlamlı düzeyde yüksek bulunmuştur. Diğer mesleki kıdem yılları arasında ise anlamlı bir fark bulunmamıştır. Bunun yanı sıra Kokkinos'un (2007) verileri de bu çalışmanın verileri ile paralellik göstermemektedir.

Kokkinos (2007) araştırma sonucunda mesleki kıdemi 10 yılın üzerinde olan öğretmenlerin duygusal tükenmişlik düzeyinin, mesleki kıdemi 10 yılın altında olanlara göre daha yüksek olduğunu ortaya koymuştur. Dönmez (2018) ile Kokkinos (2007) verilerine birlikte bakıldığında iki çalışmada da öğretmenlerin tükenmişlik düzeyleri kıdemlerine göre farklılaşmasına rağmen Dönmez'de (2018) kıdemi daha az olan öğretmenlerin tükenmişliği yüksek bulunurken Kokkinos'da (2007) kıdemi daha fazla olan öğretmenlerin tükenmişliği yüksek bulunmuştur.

Yaş değişkenine göre öğretmenlerin mesleki tükenmişlikleri anlamlı bir farklılık göstermektedir. Bu veriler Dolunay’ın (2002) verileri ile uyuşmakta olup Hock (1985) ve Yıldız'ın (2012) verileri ile uyuşmamaktadır. Bu çalışmada toplam mesleki tükenmişlikte en üst sırada 41-50 yaş grubundaki öğretmenler, sonra 27-40 yaş grubundaki öğretmenler, daha sonra da 51-64 yaş grubundaki öğretmenler yerini almaktadır. 41-50 yaş grubundaki öğretmenlerin mesleki tükenmişlik düzeylerinin kendilerinden daha genç ve daha yaşlı öğretmenlere kıyasla daha yüksek çıkmasının sebebi bu yaş grubundaki öğretmenlerin ailevi sorumluluklarının diğer yaş gruplarındaki öğretmenlere göre daha yüksek olmasından kaynaklanıyor olabilir.

41-50 yaş grubundaki öğretmenlerin ailevi sorumlulukları arasında çocuklarının üniversite eğitimlerine, iş hayatına atılmalarına ve evlilik müessesesi kurmalarına destek olmaları, bu zorlu süreçleri çocuklarıyla birlikte yaşamaları, ev veya araba gibi kendi temel 
ihtiyaçlarını karşılamak için belli uğraşlar içinde olmaları gösterilebilir. Bu yaş grubundaki öğretmenler ailevi sorumluluklarının yanı sıra mesleki zorluklarla da karşılaşınca mesleki tükenmişlik düzeylerinin yüksek çıkması olağan görülebilir. Bazı yönleriyle benzer sonuçlar içeren Dolunay’ın (2002) verilerinde ise yaş arttıkça tükenmişlik düzeyi düzenli olarak azalmaktadır. Dolunay (2002), tükenmişliğin gençlerde daha fazla görülmesinin sebebini gençlerin işle ilgili sorunlarla başa çıkma meziyetini henüz kazanmamış olmalarına bağlamıştır. $\mathrm{Bu}$ görüşe göre yaş arttıkça öğretmenlerde mesleki deneyim ve olgunluk artmakta, buna bağlı olarak da öğrenci, meslektaş, veli ve çevreyle ilgili sorunlarla başa çıkma yöntemleri gelişmekte ve nihayetinde öğretmenlerin mesleki tükenmişlik düzeyi azalmaktadır.

Sınıf öğretmenlerin iş yükü algısı ile mesleki tükenmişlik düzeyleri arasındaki korelasyon incelendiğinde anlamlı, pozitif ve orta düzeyde bir ilişki olduğu görülmektedir. Bu araştırmanın sonucu Tatlı'nın (2017) Aksaray ilinde yaptı̆̆ı araştırmasından elde ettiği iş yükü ile tükenmişlik algısı arasında pozitif doğrultuda anlamlı bir ilişki olduğu sonucu ile uyuşmaktadır. Bu sonuçlar öğretmenlerin iş yükü arttıkça mesleki tükenmişlik düzeylerinin de arttığını işaret etmektedir. Öyle ise MEB yetkilileri, il/ilçe milli eğitim müdürlükleri ve okul yöneticileri tarafından öğretmenlerin iş yükünün azaltılması ve angarya olarak görülen işlerin eğitim öğretim faaliyetlerinin önüne geçirilmemesi öğretmenlerin mesleki tükenmişlik düzeyini azaltacaktır.

Öğretmenlerin iş yükü algısı ile mesleki tükenmişliğin "mesleğe ilişkin duygusal tükenmişlik ve başarısızlık”, “öğrencilere duyarsızlaşma”, "fiziksel ve duygusal tükenmişlik", "meslektaşlara ve yöneticilere duyarsızlaşma" alt boyutları arasında toplam mesleki tükenmişlikte olduğu gibi anlaml, pozitif ve orta düzeyde bir ilişki olduğu görülmektedir. $\mathrm{Bu}$ sonuç öğretmenlerin iş yükü algısı ile mesleki tükenmişlik düzeyleri arasındaki ilişki bakımından öğretmenlerin mesleki tükenmişlik alt boyutları sonuçlarının toplam mesleki tükenmişlik düzeyine ait sonuçları destekler nitelikte olduğunu göstermektedir.

Öğretmenlerin iş yükü algısıyla mesleki tükenmişliğin dört alt boyutu arasındaki en yüksek ilişki “fiziksel ve duygusal tükenmişlik” alt boyutunda görülmüştür. Bu sonuçla öğretmenlerin iş yükü algısı ile toplam mesleki tükenmişlik düzeyleri arasındaki ilişkide "fiziksel ve duygusal tükenmişlik" alt boyutunun etkisinin diğer alt boyutlara oranla daha yüksek olduğu anlaşılmaktadır. 
Öğretmenlerin iş yükü algısı ile mesleki tükenmişliğin dört alt boyutu arasındaki en düşük ilişki “mesleğe ilişkin duygusal tükenmişlik ve başarısızlık" alt boyutunda görülmüştür. $\mathrm{Bu}$ sonuçla öğretmenlerin iş yükü algısı ile toplam mesleki tükenmişlik düzeyleri arasındaki ilişkide "mesleğe ilişkin duygusal tükenmişlik ve başarısızlık” alt boyutunun etkisinin diğer alt boyutlara oranla daha düşük düzeyde olduğu ortaya çıkmaktadır.

Araştırma sonuçlarına göre şu öneriler geliştirilmiştir: Yöneticiler öğretmenlerin çalışmalarını yakından takip ederek destek olmalı, gerektiğinde onları ödüllendirmeli ve gerek okul içinde gerekse okul dışında motivasyon artırıcı faaliyetlerde bulunmalıdırlar. Tükenmişlik düzeylerinin en aza indirilmesi için öğretmenlerin iş yükü alt düzeyde tutulmalı ve öğretmenlere eğitim öğretim faaliyetleri dışında angarya işler yaptırılmamalıdır.

Araştırmacılar öğretmenlerin iş yükü algıları ile mesleki tükenmişlik düzeyleri arasındaki ilişkiyi belirlemek için bu çalışmada olduğu gibi şehir merkezindeki okullarda görev yapan öğretmenleri değil kırsal bölgelerde görev yapan öğretmenleri kapsayacak şekilde bir araştırma yaparak bu çalışmanın sonuçları ile benzer ve farklı yönleri ortaya koyabilirler. Araştırmacılar bu çalışmada olduğu gibi resmi okullarda görev yapan öğretmenler yerine özel okullarda görev yapan öğretmenlerin iş yükü algıları ile mesleki tükenmişlik düzeyleri arasındaki ilişkiyi araştırarak bu çalışmanın sonuçları ile benzer ve farklı yönleri ortaya koyabilirler.

\section{Kaynaklar}

Akten, S. (2007). Rehber öğretmenlerin mesleki tükenmişlik düzeylerinin incelenmesi. Yüksek lisans tezi, Sosyal Bilimler Enstitüsü, Trakya Üniversitesi, Edirne.

Atik, E. (2015). Otel işletmelerinde iş yükü algısı ve iş yükünün insan kaynaklarl yönetiminde kullanımı. Yüksek lisans tezi, Sosyal Bilimler Enstitüsü, Anadolu Üniversitesi, Eskişehir.

Atlı, F. (2019). Öğretmenlerin öz-anlayışları ile mesleki tükenmişlikleri arasındaki ilişkinin incelenmesi. Yüksek lisans tezi, Sosyal Bilimler Enstitüsü, İstanbul Sabahattin Zaim Üniversitesi, İstanbul.

Bakan, H. ve Tombak, N. (2014). İdari personelin tükenmişlik düzeylerinin sosyodemografik değişkenler açısından incelenmesi: Muğla Sıtkı Koçman Üniversitesi örneği. Uluslararası Sosyal Araştırmalar Dergisi, 7(35), 681-695. 
Bivona, K. N. (2002). Teacher morale: The impact of teaching experience, workplace conditions and workload. U.S. Department of Education Office of Educational Research and Improvement.

Bolat, O. İ. (2011). İş yükü, iş kontrolü ve tükenmişlik ilişkisi. Atatürk Üniversitesi İktisadi ve İdari Bilimler Dergisi, 25(2), 87-101.

Budak, G. ve Sürgevil, O. (2005). Tükenmişlik ve tükenmişliği etkileyen örgütsel faktörlerin analizine ilişkin akademik personel üzerinde bir uygulama. Dokuz Eylül Üniversitesi İktisadi ve İdari Bilimler Fakültesi Dergisi, 20(2), 95-108.

Büyüköztürk, Ş., Çokluk, Ö. ve Köklü, N. (2010). Sosyal bilimler için istatistik. Ankara: Pegem Akademi Yayıncılık.

Büyüköztürk, Ş., Çakmak, E. K., Akgün, Ö. E., Karadeniz, Ş. ve Demirel, F. (2016). Bilimsel araştırma yöntemleri (20. Baskı). Ankara: Pegem Akademi Yayıncılık.

Cam, E. (2004). Çalışma yaşamında stres ve kamu kesiminde kadın çalışanlar. Uluslararası Insan Bilimleri Dergisi, 1(1), 1-10.

Cemaloğlu, N. ve Kayabaşı, Y. (2007). Öğretmenlerin tükenmişlik düzeyi ile sınıf yönetiminde kullandıkları disiplin modelleri arasındaki ilişki. Gazi Eğitim Fakültesi Dergisi, 27(2), 123-155.

Cerit, Y. (2008). İlköğretim okulu müdürlerinin hizmet yönelimli liderlik davranışlarının öğretmenlerin tükenmişliklerine etkisi. Kuram ve Uygulamada Ĕgitim Yönetimi Dergisi, 55, 547-570.

Croom, D. B. (2003). Teacher burnout in agricultural education. Journal of Agricultural Education, 44(2), 1-13.

Çelik, M. (2016). Tükenmişlik yaşam doyumu ve iş yükü ilişkisi: Denizli’de faaliyet gösteren muhasebe meslek mensupları üzerinde bir araştırma. Süleyman Demirel Üniversitesi Iktisadi ve İdari Bilimler Fakültesi Dergisi, 21(4), 1139-1152.

Dağdeviren, M., Eraslan, E., ve Kurt, M. (2005). Çalışanların toplam iş yükü seviyelerinin belirlenmesine yönelik bir model ve uygulaması. Gazi Üniversitesi Mühendislik ve Mimarlık Fakültesi Dergisi, 20(4), 517-525.

Dere Çiftçi, H. (2015). Özel eğitim merkezlerinde çalışan öğretmenlerin mesleki yetkinlik ve tükenmişlik düzeyleri arasındaki ilişkinin belirlenmesi. Mediterranean Journal of Humanities, 1, 221-241.

Dolunay, A. B. (2002). Keçiören ilçesi “Genel liseler ve teknik-ticaret-meslek liselerinde görevli öğretmenlerde tükenmişlik durumu” araştırması. Ankara Üniversitesi Tıp 
Fakültesi Mecmuası, 55(1), 51-62.

Dönmez, İ. (2018). Sınıf öğretmenlerinin mesleki tükenmişlik düzeylerinin çeşitli değişkenler açısından incelenmesi (hatay iskenderun ilçesi örneği). Yüksek lisans tezi, Sosyal Bilimler Enstitüsü, Biruni Üniversitesi, İstanbul.

Edelwich, J. and Brodsky, A. (1980). Burnout: Stages of disillusionment in the helping proffessions. New York, NY: Human Sciences Press.

Eggemeier, F. T., Wilson, G. F., Kramer, A. F. and Damos, D. L. (1991). Workload assessment in multi-task environments. (Ed. Diane L. Damos), Multiple-Task Performance (207-216). London: Taylor \& Francis.

Erdem, M. (2010). Öğretmen algılarına göre liselerde iş yaşamı kalitesi ve örgütsel bağlılıkla ilişkisi. Kuram ve Uygulamada Ĕ̆itim Yönetimi Dergisi, 16(4), 511-536.

Eroğlu, F. (1998). Davranış bilimleri. İstanbul: Beta Yayıncılık.

Ertürk, E. ve Keçecioğlu, T. (2012). Çalışanların iş doyumları ile mesleki tükenmişlik düzeyleri arasındaki ilişkiler: Öğretmenler üzerine örnek bir uygulama. Ege Akademik Bakış Dergisi, 12(1), 39-52.

Halis, M. (2010). İlköğretim okullarında görev yapan öğretmenlerin iş güçlüklerinin örgütsel bağlılıklarına etkisi. Dumlupınar Üniversitesi Sosyal Bilimler Dergisi, 26, 252-266.

Hock, R.R. (1985). Professional burnout among public school teachers. U.S. Department of Education Office of Educational Research and Improvement.

Huey, F.M. and Wickens, C.D. (1993). Workload transition: Implications for individual and team performance. Washington, DC: National Academy.

Ingvarson, L., Kleinhenz, E., Beavis, A., Barwick, H., Carthy, I., and Wilkinson, J. (2005). Secondary teacher workload study: Report, Australian Council for Educational Research.

Izgar, H. (2000). Okul yöneticilerinin tükenmişlik düzeyleri (burnout), nedenleri ve bazı etken faktörlere göre incelenmesi (Orta Anadolu örneği). Doktora tezi, Sosyal Bilimler Enstitüsü, Selçuk Üniversitesi, Konya.

Jones, E., Chonko L., Rangarajan D. and Roberts J. (2007). The role of overload on job attitudes, turnover intentions, and salesperson performance. Journal of Business Research, 60, 663-671.

Kahveci, Ç. (2016). Sağlık çalışanlarında iş yükünün motivasyona etkisi. Yüksek lisans tezi, Sosyal Bilimler Enstitüsü, Beykent Üniversitesi, İstanbul. 
Keleş Ay, F. (2010). Illköğretim okulu öğretmenlerinin iş yükü algısı ve iş-aile çatışması. Yüksek lisans tezi, Sosyal Bilimler Enstitüsü, Kocaeli Üniversitesi, Kocaeli.

Keser, A. (2006). Çağrı merkezi çalışanlarında iş yükü düzeyi ile iş doyumu ilişkisinin araştırılması. Kocaeli Üniversitesi Sosyal Bilimler Enstitüsü Dergisi, 11, 100-119.

Kılınç, B. (2018). Fen bilimleri öğretmenlerinin mesleki tükenmişlik düzeylerinin bazı değişkenler açısından incelenmesi. Yüksek lisans tezi, Eğitim Bilimleri Enstitüsü, Fırat Üniversitesi, Elazı ̆̆.

Kış, A. (2015). Eğitim paydaşlarının tükenmişliğinde cinsiyet farklılığı: Bir meta-analiz çalışması (Türkiye örneği). Ondokuz Mayıs Üniversitesi Eğitim Fakültesi Dergisi, 34(2), 88-106.

Kilmen, S. (2015). Eğitim araştırmacıları için SPSS uygulamalı istatistik. Ankara: Edge Akademi Yayınevi.

Kokkinos, C. M., (2007). Job stressors, personality and burnout in primary school teachers. British Journal of Educational Psychology, 77, 229-243.

Korkmazer, F. (2018). Işs yükü fazlalı̆̆ algısının yaşam kalitesi üzerindeki etkisi: İş-aile çatışmasının aracı rolü. Doktora tezi, Sosyal Bilimler Enstitüsü, İnönü Üniversitesi, Malatya.

Kramer, A. F. (1990). Physiological metrics of mental workload: A review of recent progress. San Diego, CA: Navy Personnel Research and Development Center.

Maslach, C. (1982). Burnout: The cost of caring. Cambridge, MA: Malor Books.

Maslach, C. and Jackson, S. E. (1981). The measurement of experienced burnout. Journal of Occupational Behavior, 2, 99-113.

Maslach, C. and Leiter, P. M. (1997). The truth about burnout. San Francisco, CA: JosseyBass.

Maslach, C., Schaufeli, W. B. and Leiter, M. P. (2001). Job burnout. Annual Review of Psychology, 52, 397-422.

Milli Eğitim Bakanlığı [MEB] (2018). Milli Eğitim İstatistikleri Örgün Eğitim 2017-2018. http://sgb.meb.gov.tr/www/icerik_goruntule.php?KNO=327 adresinde 04.12.2019 tarihinde alınmıştır.

Naktiyok, A. ve Karabey, C. N. (2005). İşkoliklik ve tükenmişlik sendromu. Atatürk Üniversitesi İktisadi ve İdari Bilimler Dergisi, 19(2), 179-198. 
Newhook, J. T. (2012). Task-diaries: A valuable qualitative tool for occupational health research on teacher workloads. International Journal of Qualitative Methods. 11(5), 666-683.

Ordukaya, H. (2011). Fiziksel iş yükü ve ergonomi. Anahtar Dergisi, 273-274, 42-47.

Otacıoğlu, S. G. (2008). Müzik öğretmenlerinde tükenmişlik sendromu ve etkileyen faktörler. İnönü Üniversitesi Eğitim Fakültesi Dergisi, 9(15), 103-116.

Özkalp, E. ve Kırel, Ç. (2018). Örgütsel davranış (8. Baskı). İstanbul: Ekin Yayınevi.

Özyolcu, E. (2015). Eğitim yönetimi temelinde öğretmenlerin ve yöneticilerin aşırı iş yükü, tükenmişlik ve sosyal destek durumlarının incelenmesi. Yüksek lisans tezi, Eğitim Bilimleri Enstitüsü, Yakın Doğu Üniversitesi, Lefkoşa.

Samancı, S. ve Basım, H. N. (2018). Kendilik değerlendirmeleri ve iş yükü fazlalığının mesleki tatmin üzerine etkisi: Avukatlar üzerine bir araştırma. İş ve İnsan Dergisi, 5(2), 169-184.

Sellen, P. (2016). Teacher workload and professional development in England's secondary schools: Insights from TALIS. Education Policy Institute, London.

Solmuş, T. (2004). İş yaşamında duygular ve kişilerarası ilişkiler. İstanbul: Beta Yayıncılık.

Spector, P. E. ve Jex, S. M. (1998). Development of four self-report measures of job stressors and strain: Interpersonal conflict at work scale, organizational constraints scale, quantitative workload inventory, and physical symptoms inventory. Journal of Occupational Health Psychology, 3(4), 356-367.

Sürgevil, O. (2006). Çalışma hayatında tükenmişlik sendromu tükenmişlikle mücadele teknikleri. Ankara: Nobel Akademik Yayıncılık.

Şimşek, M. (1994). Mühendislikte ergonomik faktörler. İstanbul: Marmara Üniversitesi Yayınları.

Tatlı, M. (2017). Tükenmişlik ile iş yükü arasındaki ilişki: Aksaray defterdarlı̆̆ında bir araştırma. Yüksek lisans tezi, Sosyal Bilimler Enstitüsü, Aksaray Üniversitesi, Aksaray.

Tortop, N., Aykaç, B., Yayman, H. ve Özer, M. A. (2007). Insan kaynakları yönetimi. Ankara: Nobel Akademik Yayınc1lık.

Törnük, N. (2019). Okul öncesi öğretmenlerinin tükenmişlik düzeylerinin yordayıcısı olarak mesleki sosyal destek algısı. Yüksek lisans tezi, Sosyal Bilimler Enstitüsü, İstanbul Sabahattin Zaim Üniversitesi, İstanbul. 
Tunaboylu, M. (2015). Illkokul ve ortaokul öğretmenlerinin mesleki tükenmişlik düzeyleri (İzmir ili Torball ilçesi örneği). Yüksek lisans tezi, Sosyal Bilimler Enstitüsü, Okan Üniversitesi, İzmir.

Turgut, T. (2011). Çalışmaya tutkunluk: İş yükü, esnek çalışma saatleri, yönetici desteği ve iş-aile çatışması ile ilişkileri. Atatürk Üniversitesi İktisadi ve İdari Bilimler Dergisi, 25(3-4), 155-179.

Türkçarpar, Ü. (2011). Beden eğitimi öğretmenlerinin farklı değişkenlere göre tükenmişlik düzeylerinin incelenmesi. Türkiye Sosyal Araştırmalar Dergisi, 3, 135-146.

Türkmen, C. (2010). Örgütlerde riskli meslek gruplarında çalışan personelin tükenmişlik düzeylerinin meslek doyumlarına etkisi: Denizli'de sağlık teşkilatında görev yapan kamu çalışanları üzerinde bir araştırma. Yüksek lisans tezi, Sosyal Bilimler Enstitüsü, Pamukkale Üniversitesi, Denizli.

Xhako, D. (2017). The moderating effect of percelved organizational supports (pos) in the impact of worload and work-family conflict on organizational commitment a research in hospital nurse staffing. Yüksek lisans tezi, Sosyal Bilimler Enstitüsü, Hacettepe Üniversitesi, Ankara.

Yellice Yüksel, B., Kaner, S. ve Şekercioğlu, G. (2008). Öğretmen mesleki tükenmişlik ölçeği geliştirme çalışması. I. Ulusal Eğitimde ve Psikolojide Ölçme ve Değerlendirme Kongresi. Ankara: Ankara Üniversitesi Yayınevi, 515-530.

Yıldız, E. (2012). Mesleki tükenmişlik ve rehber öğretmenler üzerine bir araştırma. Sakarya Üniversitesi Sosyal Bilimler Enstitüsü Dergisi, 33, 37-61.

Y1lmaz Toplu, N. (2012). Okul öncesi ve ilköğretim ögrretmenlerinin tükenmişlik düzeyleri. Yüksek lisans tezi, Sosyal Bilimler Enstitüsü, Adnan Menderes Üniversitesi, Aydın.

Yoğun Erçen, A. E. (2007). Öğretmenlerin mesleki tükenmişlik düzeyleri mersin ilinde karşılaştırmalı bir inceleme. Çukurova Üniversitesi Ĕ̆itim Fakültesi Dergisi, 3(34), 18.

\section{Summary}

\section{Statement of Problem}

Innovations brought to teachers, which are important building blocks of education system, differentiate their duties, responsibilities and workloads. Accordingly, the levels of vocational burnout of teachers who do not want to compromise the quality of education may be affected by innovations. Over or under workload is considered as the precursor of many 
variables such as stress, physical and mental fatigue, and decrease in job satisfaction, depression and burnout (Çelik, 2016; Maslach and Leiter, 1997; Samancı and Basım, 2018).

Teachers may have different workloads and burnout levels, as school types have different needs and objectives. The workload of primary school teachers and the workload of secondary and high school teachers may be different. In this context, it is considered appropriate to examine teachers' workload perception and occupational burnout levels according to a certain type of school. This research aims to determine the level of the relationship between workload perception and vocational burnout of classroom teachers working at official primary school depends on the ministry of education in Turkey.

\section{Method}

Quantitative method was used in this research. Since the relationship between workload perception and vocational burnout levels is determined, the research is in relational screening model. The sample of the study consists of 329 classroom teachers working in Atakum, Canik and İlkadım districts of Samsun province in the 2017-2018 academic year.

"The Personal Information Form" developed by the researchers to collect the research data, "The Workload Perception Scale For Teachers" developed by Keleş Ay (2010) to measure teachers' workload perception and "The Teacher Vocational Burnout Scale" developed by Yellice Yüksel, Kaner and Şekercioğlu (2008) to measure teachers' vocational burnout were used.

The t-test for gender, Mann-Whitney U test for marital status, ANOVA and Kruskal Wallis test for age and vocational seniority were performed to analyze the data. Tukey HSD test was used to determine the sub-dimensions that differ significantly. Pearson correlation analysis was conducted to determine the relationship between workload and vocational burnout.

\section{Findings}

When the workload perceptions of teachers and total and sub-dimensions of vocational burnout were examined, it was seen that both workloads and vocational burnout were low. The teachers agreed that at most of the workload perception is that "I support the guidance teacher in the works related to the students' personal information." The teachers agreed that "I was called to school when needed during the summer vacation." At least of the workload perception. The teachers agreed that at most of vocational burnout is that 
"Managers don't appreciate my efforts as a teacher." The teachers agreed that at least of vocational burnout is that "I often argue with my colleagues."

The teachers' perception of workload and vocational burnout do not show significant differences according to gender, marital status and vocational seniority variables. The teachers' perception of workload do not differentiate according to the age variable. The teachers' vocational burnout shows a significant difference according to the age variable. According to the data, the highest rank of teachers in total vocational burnout is 41-50 years old, the second is 27-40 years old and the lowest is 51-64 years old.

There is a significant, positive and moderate relationship between the teachers' workload perception and vocational burnout. There is a significant, positive and moderate relationship between workload perception and vocational burnout related sub-dimensions such as "emotional burnout and failure related to profession", "depersonalization to students", "physical and emotional burnout", "depersonalization to colleagues and managers". The highest relationship between workload perception and sub-dimensions of vocational burnout has been seen between "physical and emotional burnout" and the lowest relationship has been found to be between "the emotional burnout and failure related to profession" sub-dimension.

\section{Conclusion, Discussion and Recommendations}

As a result of the research, it has been found that the workload of teachers was not heavy (at low level). The result of this research does not agree with the conclusion that Keleş Ay's (2010) workload perception of teachers is moderate.

When the total and sub-dimensions of the vocational burnout are examined, it is understood that teachers do not have (at low level) a vocational burnout. The results of this research are similar to those of Cerit (2008), Türkçarpar (2011), Ertürk and Keçecioğlu (2012), Kılınç (2018) and Törnük (2019), but not with the results of Cemaloğlu and Kayabaş1 (2007). In the study of Cemaloğlu and Kayabaşı (2007), it was observed that teachers had high levels of burnout.

When the correlation between teachers' workload perception and vocational burnout levels is examined, it is seen that there is a significant, positive and medium level relationship. The result of this research is in agreement with the result that there is a positive relationship between Tatlı's (2017) workload and perception of burnout. These results indicate that as teachers' workload increases, their levels of vocational burnout increase. 
YYÜ Eğitim Fakültesi Dergisi (YYU Journal of Education Faculty), 2020; 17(1):926-958,http://efdergi.yyu.edu.tr,

According to the results of the research, the following suggestions have been developed: Administrators should closely follow the works of teachers and support them, keep the teachers’ workload at a low and should not make teachers to chores. Researchers can investigate the relationship between workload perceptions and vocational burnout levels of classroom teachers working at private schools and reveal similar and different aspects with the result of this study. 